\title{
Investment in ESG Projects and Corporate Performance of Multinational Companies
}

\author{
Victoria Cherkasova $^{1+}$ and Irina Nenuzhenko ${ }^{1}$ \\ ${ }^{1}$ National Research University Higher School of Economics (NRU HSE), Russia
}

\begin{abstract}
This study investigates whether investing in environmental, social, and governance (ESG) projects boosts corporate financial performance. It also examines whether these projects trigger the company's default due to the high costs of such projects, depending on whether the firm is multinational and its headquarter region. To obtain robust results, we conduct the examination separately for seven regions: North America, Latin America, Western Europe, Eastern Europe, Middle East and Africa, emerging Asia, and Developed Asia. We examine firm-level indicators of 1,249 companies and are headquartered in different regions for 2011-2019. We find that the company's headquarter region influences the interrelationship between financial performance and ESG activities. The most successful companies in ESG development are international companies and those headquartered in developing or Developed Asia or North America. Meanwhile, Latin American firms, both local and multinational, experience significant challenges during the implementation of ESG initiatives.
\end{abstract}

Keywords: ESG projects, international companies, financial performance, default likelihood, headquarters JEL Classifications: F21, F23, F30, G17, G 30, G39

Received 1 July 2021, Revised 20 October 2021, Accepted 22 October 2021

\section{Introduction}

The corporate social responsibility (CSR) initiatives and their influence on corporate financial performance have been actively researched lately. The term encompasses how the company contributes to the preservation of the environment, for instance, by reducing air pollutant emission, issuing green bonds, and participating in other activities, which can help solve the problem of climate change. Moreover, environmental, social, and governance (ESG) initiatives cover social issues, such as caring for employees by providing good work conditions, effective human capital management, and health and safety programs. Additionally, corporate governance is implied in ESG activities. This component examines how the firm is managed; more precisely, it analyzes

\footnotetext{
+Corresponding Author: Victoria Cherkasova

Ph.D. Candidate, Associate Professor, School of Finance, Faculty of Economic Sciences, National Research University Higher School of Economics (NRU HSE), 20 Myasnitskaya St., 101000, Moscow, Russia. Email: vcherkasova@hse.ru Co-Author: Irina Nenuzhenko

Master of science, School of Finance, Faculty of Economic Sciences, National Research University Higher School of Economics (NRU HSE), 20 Myasnitskaya St., 101000, Moscow, Russia. Email: irinanenuzhenko10@gmail.com
} 
the existence of bribery and corruption, the diversity of board structure, and the existence of remuneration system for managers (Duque-Grisales \& Aguilera-Caracuel, 2019).

Consumers, investors, and suppliers demand more and more from businesses to comply with the present sustainability trends. Hence, companies must be focused on not only operating activities and profit generation but also considering environmental, social, and managerial issues. Otherwise, firms might be exposed to financial distress and risks (Badayi et al., 2020).

Many studies have been conducted to investigate the impact of CSR on corporate financial performance (Lo \& Kwan, 2017; Fatemi et al., 2018; Yu et al., 2018; Duque-Grisales \& AguileraCaracuel, 2019; Bhaskaran et al., 2020). However, results of existing research vary; in other words, some studies revealed the positive interrelationship between ESG activities and corporate financial performance, which can be explained by the fact that the effective sustainability policy attracts more customers and investors, who, in turn, generate additional cash flows. Other authors have demonstrated the negative interrelationship between ESG activities and corporate financial performance by arguing that such project is quite expensive for some firms, and they would prefer investing in operating activities rather than in sustainability. Only a few papers are devoted to the analysis of the impact of ESG initiatives on the default probability (Devalle et al., 2017; Badayi et al., 2020). These studies have demonstrated that the increase in ESG activities triggers a lower likelihood of default, explaining this result by a reduction in the company's financial risk and distress, and the increase in the number of customers and investors. Besides the aforementioned impacts of ESG activities on the firm's indicators, researchers also pay attention to the examination of the interrelationship between ESG initiatives and the cost of capital (Gjergjiet al., 2020; Raimo et al., 2021) and conclude that this relationship is negative for large companies, whereas small and medium enterprises (SMEs) do not benefit from ESG activities.

Many studies have covered various aspects of the ESG influence on the company's financial performance; however, most are dedicated to firms of a developed market. More recent studies have tried encompassing companies of both developed and emerging markets. However, putting firms of emerging market countries, such as Argentina and China, into one group of developing countries firms, for instance, is ineffective because economic development, political stability, institutional conditions, and cultural values are different in these countries. Additionally, applying two econometric models, such as the panel data model with random or fixed effects and the ordered response logit model within one research paper would be more effective. The panel data model will help understand the dependence between ESG activities and corporate financial performance. Moreover, the ordered response logit model will then help analyze whether ESG projects may negatively influence the company's profitability and trigger the company's default due to the high costs of these projects. Finally, studies examining the impact of internationalization on the interrelationship between ESG initiatives and corporate financial performance are scant, albeit the crucial role of multinationalization in the aforementioned relationship. This is because 
when the company expands outside the domestic market, it must comply with the host's values, laws, and norms. Hence, international companies invest more in sustainability; in turn, foreign customers and investors will generate more cash flows or vice versa, and the simultaneous costs of internationalization and sustainability may cause the company's default.

Consequently, the relevance of this study is identified by the importance of the ESG activity implementation, because such activities will help preserve the environment, for example, by reducing air pollutant emission, encourage employees to work more productively by enhancing work conditions, and improve the effectiveness of corporate governance. Not all companies can afford to implement these projects; hence, knowing which companies cannot introduce ESG projects without making a loss and offer support programs for such firms is vital.

This study primarily aims to investigate how ESG activities influence corporate financial performance, whether ESG initiatives boost the company's financial performance or vice versa, which may cause the company's default due to the costliness of such projects.

Lately, a great deal of theoretical and empirical studies are dedicated to examining the impact of ESG initiatives on corporate financial performance and the company's likelihood of default. For instance, Cheng et al. (2014), Arayssi et al. (2016), Shaukat et al. (2016), Garcia et al. (2017), Yu et al. (2018), Fatemi et al. (2018), Duque-Grisales and Aguilera-Caracuel (2019), MirallesQuirós et al. (2019), Nekhili et al. (2021), Bhaskaran et al. (2020), De Lucia et al. (2020), and Crespi and Migliavacca (2020) analyzed how investing in ESG projects may boost the market value of a firm and profitability measures, such as return on assets (ROA) and return on equity (ROE). Meanwhile, Sun and Cui (2014), Devalle et al. (2017), and Badayi et al. (2020) explored the influence of ESG initiatives on the default likelihood.

However, none of the authors considered the specific features of the region where the company is headquartered and the effect of the company's internationalization on the relationship between corporate financial performance and ESG activities. They have also not considered the relationship between default likelihood and ESG initiatives.

Firstly, this study encompasses separately seven regions where firms are headquartered: North America, Latin America, Western Europe, Eastern Europe, Middle East, and Africa, emerging Asia, and Developed Asia. We have not grouped emerging market countries into one group. For instance, Latin American firms are not comparable to developing Asian countries like China and India, with fast-growing economies. Thus, investigating the interrelationship between ESG activities and corporate financial performance by splitting the data sample into regions is more efficient and reliable.

Moreover, we conduct a comparative analysis between regions. We proved that the most successful regions in engaging in ESG activities are North America, Developed Asia, and Developing Asia. Eastern European firms demonstrate effective implementation of ESG operations, which could be attributed to their proximity to Western Europe. Finally, because of the high level of corruption, 
political uncertainty, and political instability in some nations in these regions, the Middle, Africa, and Latin America does not benefit from the ESG project execution.

Third, the empirical study combines two econometric models, namely, the panel data model with random or fixed effects and the ordered response logit model. The first type of model helps determine the character of the dependency between CSR activities and corporate financial performance. The second model helps analyze, whether CSR projects negatively influence the company's profitability and trigger the company's default due to the high costs of these projects.

Fourth, the study includes investigating how internationalization affects the dependence between CSR activities and corporate financial performance. This empirical study is relevant for the investors who want to invest in companies engaging in ESG activities because the study's results reveal which companies benefit from investing in sustainability and which do not.

The remainder of this study is organized as follows. The next section includes the analysis of the relevant existing literature and the hypothesis formulation. Then, the data, dependent and independent variables, methodology, and the econometric analysis are presented. Lastly, the main findings and suggestions for further empirical studies are presented.

\section{Literature Review}

The relationships between the firm's financial performance and ESG activities have been extensively researched over the past years, but the results of existing studies are controversial. Most studies are devoted to investigating how engagement in ESG initiatives impacts corporate financial performance, cost of capital, and the probability of default.

\section{A. ESG activities/disclosure and corporate financial performance}

Fatemi et al. (2018) examined the influence of ESG activities and their disclosure on firm market value by employing a two-stage model for 403 US companies from 2006 to 2011. The authors conjectured that the interrelationship between ESG activities and firms' financial performance is strictly positive. Moreover, they assumed that through ESG disclosure, companies try differentiating themselves from less successful performers and escape the effects of adverse selection. The results of their investigation demonstrate that the increase in ESG activities leading to higher firm market value, whereas the intensity of disclosure information regarding ESG weakens the company's market value. Further, Fatemi et al. (2018) explained the second result that strengthening of ESG transparency might be interpreted by the market as the company's effort to justify unnecessarily excessive investments in ESG activities.

Meanwhile, Yu et al. (2018) continued the examination of the interrelationship between ESG 
transparency and firm market value and drew a conclusion that is opposite with that of Fatemi et al. (2018). By investigating 1,996 large capital firms located in 47 emerging and developed countries, the authors found that companies will be encouraged to disclose ESG data alongside the financial data needed to be reported to shareholders. Yu et al. (2018) also demonstrated that ESG transparency boosts Tobin's Q by lessening information asymmetry of investors and agency costs, whereas other studies illustrated the same dependence (Cheng et al., 2014; Nekhili et al., 2021). Moreover, $\mathrm{Yu}$ et al. (2018) specified that one of the primary factors behind sustainability is the economic development of the country where the firm is based. This is because the wealthier the country, the more people require businesses to participate actively in ESG initiatives because people from developed countries are better informed about new tendencies and world problems. This finding is confirmed by other studies (Miralles-Quirós et al., 2019; Duque-Grisales \& Aguilera-Caracuel, 2019; Crespi \& Migliavacca, 2020).

By examining 4,886 firms from emerging and developed countries and applying a two-stage least square model, Bhaskaran et al. (2020) confirmed that companies investing in ESG projects tend to enhance their market value. The authors highlighted other factors strengthening these relationships. For instance, cash-rich companies tend to invest more in environmental activities that help reduce air pollutant emission, which appeals to new customers and investors. The larger the company, the more resources are available to invest in shareholders' welfare. Further, Bhaskaran et al. (2020) emphasized that companies actively investing in welfare initiatives for workers create higher firm value and operating performance because highly motivated workers will demonstrate increased productivity in the more favorable working climate.

Some studies have analyzed the relationship between ESG initiatives and the financial performance of companies by country. For instance, Lo and Kwan, 2017 analyzed Hong Kong companies and concluded that ESG activities positively affect market reaction; however, this dependence is weak. Moreover, having analyzed Malaysian companies from 2005 to 2018, Wong et al. (2021) discovered that, on average, ESG initiatives boost Tobin's Q by 31.9 percent. The authors identified that the amount of cash holding plays an important role in strengthening the aforementioned relationship. This conclusion agrees with the findings of Bhaskarans et al. (2020).

Other researchers attempted to examine how the corporate board structure may influence the dependence between sustainability disclosure and the stakeholders' welfare (Arayssi et al., 2016; Shaukat et al., 2016). For example, Arayssi et al. (2016) discovered that the existence of women in corporate boards leads to effective investments in social initiatives and their disclosure that then enhances corporate financial performance.

Having examined the firm-level data of 365 companies from BRICS from 2010 to 2012, Garcia et al. (2017) revealed that Russia and Brazil demonstrate the increasing level of ESG performance, whereas South Africa and India cannot achieve the same high level of the ESG indicator. Meanwhile, China shows a diminishing level of social and environmental indicators, 
but its governance performance enhances. The study primarily concluded that firms operating in sensitive industries, such as tobacco, gambling, military, alcohol, nuclear, chemicals, oil, and gas, demonstrate high ESG indicators and tend to disclose better performance. Moreover, these factors positively affect corporate financial metrics. The reason is that firms operating in sensitive industries are exposed to more control, and they engage in sustainable activities to reduce the negative effect on the environment and to improve their reputation. Furthermore, Garcia et al. (2017) highlighted the crucial role of free cash flow in highly positive dependence between ESG initiatives and corporate financial performance (Wong et al., 2021; Bhaskaran et al., 2020).

Meanwhile, De Lucia et al. (2020) analyzed whether the intensity of ESG practices results in the improved financial performance of public enterprises and confirmed this assumption. Friede et al. (2015) determined that approximately 90 percent of extant studies show the nonnegative interrelationship between ESG practices and corporate financial performance. More recent studies continue demonstrating the same results.

However, Duque-Grisales and Aguilera-Caracuel (2019) detected the negative interrelationship between ESG activities and firms' financial performance while analyzing the financial data of 104 multinational companies headquartered in Latin America from 2011 to 2015. The authors emphasized that Latin American firms differ considerably from their competitors belonging to developed markets by managerial, cultural, ethical, and social practices. Moreover, Latin American firms may not consider ESG activities as a priority, because these initiatives are invisible and financial resources are constrained. Latin American companies suffer from scarcity of financial resources, and their managers focus on operating business activities to survive rather than expensive ESG projects. However, the authors identify that if the availability of funding increases, investment in ESG projects will begin positively affecting corporate financial performance. Firms may afford to hire professional staff possessing special knowledge and abilities to produce more efficient outcomes in the ESG activities. Duque-Grisales and Aguilera-Caracuel (2019) determined that the higher international sales of the firm, the stronger the positive influence of ESG activities on corporate financial performance. This is because foreign customers may demand from companies active participation in ESG initiatives, whereas foreign investors can provide additional funding for such initiatives.

Duque-Grisales and Aguilera-Caracuel (2019) continued confirming the importance of free cash flow in the relationship between ESG activities and corporate financial performance. Also, they investigated how ESG initiatives affect the cost of capital, credit rating, and default likelihood of companies.

\section{B. ESG initiatives and companies' cost of capital, credit rating, and default likelihood}

ESG activities can influence the probability of default in various ways. First, clients prefer 
purchasing goods produced by companies that care about the environment and working conditions for their employees and those that try implementing best managerial practices. Therefore, ESG initiatives result in increased client satisfaction and consequently increases total sales, leading to an increase in cash flow and a decrease in the likelihood of the company's default (Sun and Cui, 2014). Second, ESG practice may reduce the likelihood of default occurrence by declining the firm's financial risk and financial distress. The firm risk may rise if the company faces sanctions or lawsuits because of daily activities that negatively affect the environment or other social indicators. Moreover, the government can abruptly introduce new law prohibiting emission above a defined threshold, and hence, the company's operations will be threatened (Badayi et al., 2020). Third, if the company actively participates in ESG initiatives, stakeholders might be confident in the firm's future prosperity without sanctions and lawsuits caused by the company's operating activities that lead to social and environmental damages. In turn, good relations with stakeholders provide the company with alternative funding sources, declining its need in debt and lowering its risk of default (Jo \& Na, 2012).

Having examined 56 Spanish and Italian firms by applying an ordered logistic regression model, Devalle et al. (2017) revealed the positive influence of ESG initiatives on the company's credit rating at a 1 percent level of significance. The authors highlighted that ESG activities reduce the company's risk and remarked the necessity for including ESG in the credit rating assessment. A more recent study (Badayi et al., 2020) confirms the aforementioned positive relationship based on the analysis of 496 companies located in 17 countries of the emerging market.

Regarding the influence of ESG initiatives on the cost of capital, Wong et al. (2021) demonstrated that increasing ESG practice reduces the cost of capital by 1.2 percentage points on average. By examining the data sample consisting of 919 international companies operating in various industries during the 2010-2019 period, Raimo et al. (2021) concluded that ESG disclosure negatively affects the cost of debt. They explained this by reporting ESG activities that help potential lenders effectively investigate how the company operates using financial data and analyzing sustainable report revealing, for instance, air pollutant emission, work conditions, human rights, governance structure, and other ESG aspects. Potential lenders can receive more information, and thus, their awareness of overall business is greater, leading to lower cost of debt. Gjergji et al. (2020) noted that SMEs most likely will not receive benefits of ESG initiatives in the form of lower cost of capital. The primary reason for that is the tradeoff between benefits and costs. SMEs may not possess sufficient knowledge and abilities to effectively implement ESG practices and disclose them. They may also lack a significant number of financial resources.

The existing studies have covered many aspects, including the analysis of the impact of ESG activities and their disclosure on corporate financial performance, cost of capital, and the company's default probability. However, they divided the data sample into developed and emerging markets. For instance, countries of Latin America are not comparable to developing Asian countries, 
such as China and India with fast-growing economies; hence, we cannot group these countries into one group. That is, it will be more robust to investigate the interrelationship between ESG activities and corporate financial performance by splitting the data sample into regions. Hence, our research will cover seven regions separately: North America, Latin America, Western Europe, Eastern Europe, Middle East, Africa, emerging Asia, and Developed Asia. Additionally, we will combine two regression models, namely, the panel data model with random or fixed effects and the ordered response logit model, which will help determine the relationship between ESG activities and corporate financial performance. Moreover, we will prove that ESG practices may not only negatively affect the company's profitability but also cause the company's default due to the costliness of such practices. Moreover, few empirical studies considered the moderating effect of internationalization in the relationship between ESG activities and corporate financial performance, albeit the crucial role that multinationalization plays in the aforementioned dependence. Consequently, our empirical study will investigate whether the company's internationalization strengthens the relationship between corporate financial performance and investment in ESG projects.

\section{Hypotheses}

ESG initiatives and their disclosure positively affect corporate financial performance by enhancing the relationship with various stakeholders, appealing to new customers and investors, and declining information asymmetry and agency costs (Cheng et al., 2014; Arayssi et al., 2016; Lo and Kwan, 2017; Fatemi et al., 2018; Yu et al., 2018; Nekhili et al., 2017; Bhaskaran et al., 2020; De Lucia et al., 2020; Wong et al., 2021).

H1: Investing in ESG projects boosts corporate financial performance.

The authors (e.g., Garcia et al., 2017; Duque-Grisales \& Aguilera-Caracuel, 2019; Bhaskaran et al., 2020; Wong et al., 2021) mentioned that free cash flow plays a crucial role in the relationship between ESG practices and corporate financial performance because of the costliness of ESG project implementation. Therefore, scarcity of financial resources, increasing debt to fund this project, and ineffective ESG project implementation may trigger company default. Meanwhile, ESG initiatives decrease the likelihood of default occurrence by appealing to new customers (Sun \& Cui, 2014), decreasing the firm's financial risk and financial distress (Badayi et al., 2020), and strengthening the relationship with stakeholders that may provide alternative capital instead of debt raising (Jo \& $\mathrm{Na}, 2012$ ).

H2: Investment in ESG projects decreases the likelihood of the company default. 
Internationalization demands companies to comply with the international or host countries' values, laws, and norms. Hence, multinational firms are assumed to be more induced to engage in ESG activities. In turn, foreign customers and investors attracted by the company's sustainability will generate more cash flow and provide additional funding, respectively (Park, 2018).

H3: Internationalization of the company strengthens the relationship between corporate financial performance and ESG project investment.

Many authors (e.g., Yu et al., 2018; Miralles-Quirós et al., 2019; Duque-Grisales \& AguileraCaracuel, 2019; Badayi et al., 2020; Crespi \& Migliavacca, 2020) revealed that the economic development of the country, in which the firm is headquartered, has a meaningful influence on the interrelationship between corporate financial performance and ESG activities. This is because people from developed countries are better informed about the importance of preservation of the environment, observance of human rights, and other social issues. Moreover, they require businesses to comply with these values; otherwise, people may boycott goods produced by firms ignoring sustainability.

H4: A country's characteristics affect the relationship between corporate financial performance and ESG project investment.

The region where the company is headquartered plays an important role in the interrelationship between ESG activities and corporate financial performance. First, when the company expands its business outside the home region, initially, the company finds difficulty adjusting to new cultural values and norms; therefore, the company continues to work with habitual cultural values and norms peculiar to the home region, and the dependence between ESG activities and corporate financial performance does not change. Second, if the company's home region is adjacent to more developed regions, where firms actively participate in ESG activities, less developed regions will gradually learn from their experience and impose projects aimed at achieving sustainability to keep up with peers from more developed regions. Third, firms headquartered in a poor region, where corruption, political uncertainty, and poor institutional conditions are common, find it challenging to implement ESG projects. Hence, when the company from this region intends to expand their business beyond the domestic region, sufficient financial resources are needed for business expansion and implementation of ESG initiatives because foreign investors and customers actively demand compliance with new sustainability trends. Consequently, these simultaneous costs may trigger the inverse correlation between corporate financial performance and ESG initiatives.

H5: The region where the company is headquartered affects the relationship between financial performance and investing in ESG projects. 


\section{Methodology}

The research focuses on investigating two econometric models: (1) the random or the fixed effects model (the choice depends on the Hausman test results and explanatory variables characteristics) and (2) the multi-year ordered response logit model.

The main research questions are whether the company's internationalization strengthens the relationship between financial performance and investing in ESG projects and whether the region in which the company is headquartered affects the relationship between financial performance and investing in ESG projects. The panel data model is applied to answer the questions. Initially, separately for each region, we investigate how ESG activities affect corporate financial performance measured through ROA, ROE, and Total Market Value to Total Asset Value of the firm:

$$
\begin{aligned}
& R O A_{i t} / R_{\text {RE }} / \text { Total Market Value to Total Asset } \text { Value }_{i t}=a_{i}+\beta_{1} \times \\
& \text { CSR performance } i t+\beta_{2} \times \text { Capex intensity } \text { it }_{i}+\beta_{3} \times \text { Financial slack }_{i t}+\beta_{4} \times \text { Size }_{i t}+ \\
& \beta_{5} \times \text { Leverage ratio }_{i t}+\beta_{6} \times \text { GDP } \text { growth }_{i t}+\varepsilon_{i t}
\end{aligned}
$$

Subsequently, we add the moderating effect of internationalization and analyze how it influences the interrelationship between ESG activities and corporate financial performance:

$$
\begin{aligned}
& \text { ROA }_{i t} / \text { ROE }_{i t} \text { Total Market Value to Total Asset } \text { Value }_{i t}=a_{i}+\beta_{1} \times \text { Multinational }_{t}+ \\
& \beta_{2} \times \text { Multinational } \# C S R \text { performance }_{i t}+\beta_{3} \times C S R \text { performance } i t+\beta_{4} \times \\
& {\text { Capex } \text { intensity }_{i t}+\beta_{5} \times \text { Financial slack }}_{i t}+\beta_{6} \times \text { Size }_{i t}+\beta_{7} \times \text { Leverage ratio }_{i t}+ \\
& \beta_{8} \times G D P \text { growth }_{i t}+\varepsilon_{i t}
\end{aligned}
$$

The second part of the research analyzes that ESG project investments may affect the likelihood of the company's default due to the high cost of these projects. Not all companies can afford ESG projects, and investment in business expansion is more relevant and profitable for such firm.

The maximum likelihood method is the most appropriate method because it is applied in cases where a dependent variable can be only a finite number. The companies are split into three groups according to their credit rating calculated based on financial indicators such as EBITDA interest coverage, total debt/EBITDA, total debt/total assets; that is, $y_{i t}=1$ if a credit rating is $\mathrm{B}$ or $\mathrm{CCC}, y_{i t}=2$ if a credit rating is $\mathrm{A}, \mathrm{BBB}$, or $\mathrm{BB}$, and $y_{i t}=3$ if a credit rating is AAA, AA, or higher (Table 1). 
Table 1. S\&P Key Industrial Financial Ratios, Long-Term Debt

\begin{tabular}{lccccccc}
\hline & AAA & AA & A & BBB & BB & B & CCC \\
\hline EBITDA interest Coverage & 31.0 & 21.4 & 12.8 & 7.6 & 4.6 & 2.3 & 1.2 \\
Total debt/EBITDA & 0.5 & 1.0 & 1.6 & 2.2 & 3.2 & 5.4 & 7.7 \\
Total debt/(total debt + equity) & $12.6 \%$ & $36.1 \%$ & $38.4 \%$ & $43.7 \%$ & $51.9 \%$ & $74.9 \%$ & $100.6 \%$ \\
\hline
\end{tabular}

Source: $S \& P$

The multi-year ordered response logit model can be written as:

$$
\begin{aligned}
& y^{*}{ }_{i t}=x_{i t}{ }^{\prime} \beta+\varepsilon_{i t}, \text { where } y^{*} \text { it is a latent variable } \\
& Y=\left\{\begin{array}{l}
1, \text { if } y^{*} \leq \mu_{1}, \\
2, \text { if } \mu_{1}<^{*} \text { it } \leq \mu_{2}, \\
3, \text { if } y^{*}>\mu_{2},
\end{array}\right.
\end{aligned}
$$

The probabilities of being in one of the three categories can be expressed as:

$$
\begin{aligned}
& \left\{y_{i t}=1 \mid x_{i t}\right\}=\left\{y^{*} i t \leq \mu_{1} \mid x_{i t}\right\}=\left(\mu_{1}-x_{i t}^{\prime} \beta\right) \\
& \left\{y_{i t}=3 \mid x_{i t}\right\}=\left\{y^{*}{ }_{i t}>\mu_{2} \mid x_{i t}\right\}=1-\left(\mu_{2}-x_{i t}^{\prime} \beta\right) \\
& \left\{y_{i t}=2 \mid x_{i t}\right\}=\left(\mu_{2}-x_{i t}^{\prime} \beta\right)-\left(\mu_{1}-x_{i t}^{\prime} \beta\right)
\end{aligned}
$$

\section{Data}

This study focused on the firm-level indicators of 1,249 companies that generate over 1-billiondollar annual revenue and are headquartered in various regions, including North America, Latin America, Western Europe, Eastern Europe, Middle East, and Africa, emerging Asia, and Developed Asia from 2011 to 2019. The table of the selected countries is submitted in Appendix 1. The firm-level data, including ESG rating, were taken from Bloomberg, whereas the macroeconomic indicator was obtained from the World Bank. The firm-level metrics applied to describe the corporate financial performance and the relationship between the financial performance of the company and investment in ESG projects; they were chosen based on the previous appropriate empirical studies (Devalle et al., 2017; Duque- Grisales and Aguilera- Caracuel, 2019; Bhaskaran et al., 2020).

\section{A. Dependent variables}

The first part is devoted to examining the relationship between the financial performance 
of the company and investing in ESG projects. The dependent variable is the company's financial performance measured through proxy variables such as ROA, ROE, and the ratio of Total Market Value of firm to Total Asset Value of firm, which is widely applied in numerous empirical studies (Yu et al., 2018; Duque-Grisales \& Aguilera-Caracuel, 2019; Bhaskaran et al., 2020). Dependent variables help analyze the influence of investment in ESG projects on the company's financial performance through accounting-based and market-based performances.

The second part is dedicated to investigating how investment in ESG projects affects the risk of the company defaulting due to these projects' high expense. The dependent variable is the likelihood of the company's default measured through its credit rating that considers the ability and willingness of the firm to meet its financial obligations on time (Devalle et al., 2017).

\section{B. Independent variables}

\section{Independent variables for the first model}

The primary independent variables are the following:

- ESG performance. It is approximated by the ESG score, retrieved from Bloomberg, and shows the company's ESG rating from 0 to 100 . ESG initiatives may influence distinctly corporate financial performance. On the one hand, these initiatives boost the company's performance by appealing to new customers and investors who prefer sustainability-oriented firms (Lo and Kwan, 2017; Fatemi et al., 2018; Yu et al., 2018; Bhaskaran et al. 2020). On the other hand, ESG projects are costly and may decrease the company's profitability (Duque-Grisales and Aguilera-Caracuel, 2019).

- Multinationalization. It is measured as the existence of a company's revenue generated beyond a home country.

- Moderating effect of the internationalization in the interrelationship between ESG activities and corporate financial performance. Multinational companies are expected to have more incentives to engage in ESG activities because internationalization is supposed to keep company managers from engaging in illegitimate behavior and encourage them to work toward enhancing sustainability (Park, 2018). However, the influence of investing in ESG projects on the firm's financial performance can be ambiguous for international companies because it can appeal to more foreign customers and investors, but the cost of these projects is sufficiently high.

This study also involves the following explanatory variables that may affect the corporate financial performance and indirectly affect the relationship between the company's financial performance and investing in ESG projects:

- Firm size is measured as the logarithm of total annual revenue and assumed to strengthen corporate financial performance because the greater the size, the greater resources, and 
opportunities are available that lead to economies of scale (Lopez-Valeiras et al., 2016).

- Capex intensity is approximated through the ratio of capital expenditure to total assets, and companies with high capital expenditures may allow more investments in stakeholder welfare and business expansion (Bhaskaran et al., 2020).

- Financial slack/current ratio is measured as the ratio of current assets to current liabilities and indicates the degree of liquid assets, the higher level of liquid assets is, the more resources are available to invest in operating activities and ESG projects (Aguilera-Caracuel et al., 2015; Duque-Grisales \& Aguilera-Caracuel, 2019).

- Leverage ratio is calculated as the ratio of long-term debt to total equity. Moreover, high indebtedness of the firm weakens corporate financial performance and the relationship between financial performance and investing in ESG projects because, in this case, interest expenses and the probability of bankruptcy and financial distress are greater (Nollet et al. 2015; Duque-Grisales \& Aguilera-Caracuel, 2019).

- GDP growth is expected to have a positive impact on corporate financial performance and the relationship between financial performance and ESG activities because GDP growth reflects the economic development of the country. Hence, the higher economic development of the country, the better the company's conditions. People from developed countries are more aware of the importance of ESG activities and require businesses to comply with new values and norms (Yu et al., 2018; Miralles-Quirós et al., 2019; Duque-Grisales \& Aguilera-Caracuel, 2019; Badayi et al., 2020; Crespi \& Migliavacca, 2020).

\section{Independent variables for the second model}

The primary independent variables are ESG performance and moderating effect of internationalization in the interrelationship between ESG activities and the company's default probability, which is already described above.

The explanatory variables for the second part of the study, which are highly connected to the likelihood of the company default and credit rating, are the following:

- EBIT to Total Revenue reflects the company's profitability and may favorably affect credit rating declining the default probability. The higher company profitability is, the higher likelihood that the company will be affordable to cover its financial obligations is (Devalle et al., 2017).

- The higher level of leverage measured as the ratio of long-term debt to total equity is, the higher likelihood of default occurrence is, because heavy indebtedness may cause inability to repay both interest and principal expenses, violation of covenants, and other negative effects.

- Firm size is approximated through logarithms of Total Revenue and Market Capitalization and negatively relates to the default probability because the larger the company is, the more stable its cash flows are (Badayi et al., 2020). 


\section{Results}

Table 2 reflects the descriptive statistics, involving standard deviations, minimum and maximum values and means. Correlation matrices are submitted in Appendices 2-5.

Table 2. Descriptive Statistics

\begin{tabular}{|c|c|c|c|c|c|c|c|c|}
\hline \multirow{2}{*}{ VARIABLES } & \multicolumn{4}{|c|}{ International companies } & \multicolumn{4}{|c|}{ Local companies } \\
\hline & mean & $\mathrm{sd}$ & Min & $\max$ & mean & $\mathrm{sd}$ & $\min$ & $\max$ \\
\hline $\begin{array}{l}\text { ESG performancel } \\
\text { ESG Rating }\end{array}$ & 36.14 & 14.74 & 3.31 & 73.97 & 27.94 & 13.02 & 3.29 & 73.97 \\
\hline$R O A$ & 5.02 & 4.95 & -21.94 & 62.71 & 4.63 & 4.93 & -44.45 & 120.81 \\
\hline $\begin{array}{l}\text { Financial Slack/ } \\
\text { Current Ratio }\end{array}$ & 1.72 & 0.93 & 0.22 & 11.85 & 1.46 & 1.13 & 0.16 & 21.34 \\
\hline CAPEX Intensity & 7 & 9.64 & 0.03 & 196.78 & 8.12 & 11.28 & 0.03 & 156.07 \\
\hline$R O E$ & 12,59 & 16.61 & -134.29 & 238.68 & 12.02 & 15.91 & -151.63 & 370.45 \\
\hline Debt-to-Equity & 83.96 & 122.73 & 0 & 3747.09 & 96.01 & 162.14 & 0 & 5611.31 \\
\hline Total Market/Total Asset & 109.11 & 83.3 & -6.15 & 1266.35 & 101.65 & 90.25 & -7.1 & 1177.39 \\
\hline EBIT to Total Revenue & 10.22 & 9.86 & -111.13 & 167.25 & 9.32 & 10.14 & -28.35 & 290.23 \\
\hline GDPgrowth & 1.89 & 1.61 & -4.71 & 11.2 & 3.09 & 2.76 & -4.71 & 13.38 \\
\hline lnMarketCap & 22.36 & 1.47 & 17.94 & 27.65 & 21.89 & 1.29 & 17.89 & 26.35 \\
\hline LnRevenue & 22.56 & 1.16 & 20.73 & 26.97 & 22.26 & 1 & 20.72 & 26.27 \\
\hline Creditrating & 2.07 & 0.59 & 1 & 3 & 2 & 0.67 & 1 & 3 \\
\hline
\end{tabular}

Source: the authors' calculations

Following the table, the data was divided into international and local firms. On average, the ESG rating for international companies is equal to 36.14, which is slightly higher than for local companies. Local companies show lower values of profitability measures such as ROE and ROA compared with international ones on average. The debt-to-equity ratio varies significantly within the data sample for both multinational and local companies and equals 122.73 percentage points and 162.14 percentage points, respectively. The current ratio might be considered as good for both international and local firms and on average equals 1.72 and 1.46, respectively. The table reflects that the exceedance of Total Market Value over Total Asset Value is higher for international companies than that for local ones. Domestic firms have a bit higher average 9-year capital expenditure intensity compared with multinational ones. On average, the EBIT margin of international companies is above that of domestic firms and equals 10.22 that is considered a healthy margin. It can be seen that both multinational and local firms mostly have credit ratings A, BBB, $\mathrm{BB}$, which corresponds to the second credit rating group. And the size of selected firms is almost equal because we have chosen only firms earning higher than 1 billion dollars per year.

Having analyzed the sample's descriptive statistics, we can conclude that international firms demonstrate better financial performance and higher ESG rating than local ones; domestic firms 
illustrate financial results not significantly worse than those of international ones. Both domestic and international firms represent a healthy average current ratio. In addition, their average debtto-equity ratio is lower than 100 percent. This concludes that selected companies do not suffer from a lack of financial resources and heavy indebtedness, and these firms can afford to invest in ESG projects. We can assume that investing in ESG projects boosts the company's financial performance, and the firm's internationalization strengthens this relationship. We will analyze whether the region where the company is headquartered affects the relationship between financial performance and investing in ESG projects.

\section{A. Latin America}

Latin America is considered an unstable region exposed to corruption, crises, political uncertainty, and weak corporate governance. Hence, implementing projects devoted to CSR under such conditions is difficult. ESG projects require a sufficient amount of money, especially for firms of Latin America, most of which still apply outdated technologies producing emission of air pollutants and must replace their equipment to minimize the negative impact on the environment. Latin American firms may suffer from the scarcity of financial resources and do not consider investing in ESG development a high-priority activity. Internationalization might positively affect the relationship between ESG activities and firm's financial performance because foreign customers may have considerable demand for goods produced by firms with high ESG ratings, and foreign investors might be interested in enhancing sustainability and providing additional financial support resources to fund ESG projects.

Figure 1 illustrates the gradual increase in the average value of the ESG score from 2011 to 2019. However, international companies demonstrate higher ESG rating compared with local ones, because of the additional sources of capital and the pressure from foreign customers, workers, and suppliers desiring the introduction and development of ESG activities.

Figure 1. The difference in ESG ratings between international and local firms from 2011 to 2019

$(1$ = international firms, $0=$ local firms)

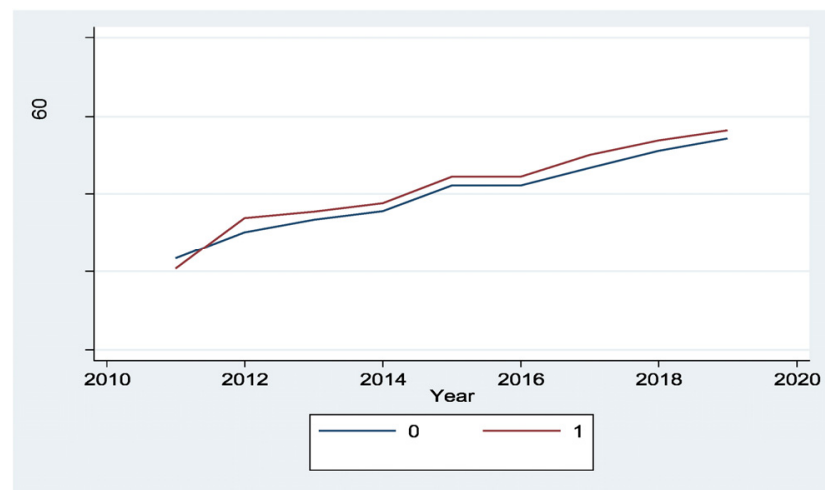


Table 3 shows the results of the regression analysis.

Table 3. The Relationship between Financial Performance and Investment in ESG Projects in Latin America

\begin{tabular}{|c|c|c|c|c|c|c|}
\hline VARIABLES & $\begin{array}{c}\text { Latin America } \\
\text { (ROA1) }\end{array}$ & $\begin{array}{c}\text { Latin America } \\
\text { (ROA2) }\end{array}$ & $\begin{array}{c}\text { Latin America } \\
\text { (ROE1) }\end{array}$ & $\begin{array}{c}\text { Latin America } \\
\text { (ROE2) }\end{array}$ & $\begin{array}{c}\text { Latin America } \\
\text { (Market/Book1) }\end{array}$ & $\begin{array}{l}\text { Latin America } \\
\text { (Market/Book2) }\end{array}$ \\
\hline Mult & & 2.105 & & 5.399 & & $62.42 * *$ \\
\hline ESG performance & $-0.0512 * * *$ & 0.00623 & -0.0988 & 0.0900 & $-0.530 * *$ & 0.463 \\
\hline $\begin{array}{l}\text { Mult\#ESG } \\
\text { performance }\end{array}$ & & $-0.0943 * * *$ & & $-0.313 * *$ & & $-1.571 * * *$ \\
\hline lnRevenue & -0.301 & 0.0516 & -0.0745 & 1.464 & -7.079 & -6.122 \\
\hline CurrRatio & 0.0917 & 0.166 & -2.290 & -1.962 & -2.508 & -2.380 \\
\hline CAPEX intensity & $-0.0483 * *$ & $-0.0442 * *$ & $-0.153^{*}$ & -0.139 & 0.487 & $0.569 *$ \\
\hline DebtEquity & -0.000594 & -0.000510 & $0.0106^{* * *}$ & $0.0109 * * *$ & 0.00926 & 0.00959 \\
\hline GDPgrowth & $0.326 * * *$ & $0.322 * * *$ & $0.956^{* * *}$ & $0.941 * * *$ & $6.912 * * *$ & $6.843 * * *$ \\
\hline Constant & 13.85 & 4.637 & 22.19 & -15.65 & $295.6^{*}$ & 234.2 \\
\hline Observations & 522 & 522 & 522 & 522 & 522 & 522 \\
\hline Number of Ticker & 58 & 58 & 58 & 58 & 58 & 58 \\
\hline
\end{tabular}

Initially, we analyze the impact of ESG performance applying econometric models without the moderating effect of internationalization on the relationship between ESG activities and corporate financial performance. According to the econometric results of models ROA1, ROE1, and Market/Book1, ESG initiatives are negatively related to corporate financial performance measured through ROA and Total Market Value of the firm to Total Asset Value of firm. According to the model ROA1, if ESG performance rises by 1 unit, ROA declines by 0.0512 percentage points. As for model Market/Book 1, if ESG performance increases by 1 unit, the ratio of Total Market Value of firm to Total Asset Value of the firm decreases by 0.53 percentage points. Further, we investigate the impact of ESG performance using models with the aforementioned moderating effect. The Internationalization of Latin American firms reduces the influence of ESG activities on corporate financial performance. If the company's sales extend beyond a domestic country, the increase in ESG performance triggers a decline in ROA by 0.0943 or ROE by 0.313 percentage points. Finally, internationalization causes a decline in the ratio of Total Market Value of firm to Total Asset Value of firm by 1.571 percentage points. ROA2, ROE2, Market/Book2, ESG performance effect becomes insignificant for domestic firms. An increase in GDP growth of the country, in which the firm is headquartered, leads to better corporate financial performance.

Notice that the likelihood of default is proxy by corporate credit rating, companies with the highest credit ratings and the lowest probability of default (AAA, AA) are categorized in 
the third group, whereas companies with the lowest credit ratings and the highest likelihood of default $(\mathrm{B}, \mathrm{CCC})$ is put into the first group.

Table 4. Regression Analysis of the Changes in the Likelihood of Default

\begin{tabular}{lcc}
\hline \multirow{2}{*}{ VARIABLES } & $(1)$ & $(4)$ \\
\cline { 2 - 3 } Mult & Latin America & Odds ratio \\
ESG performance & $-1.749^{* * *}$ & $0.174^{* * *}$ \\
Mult\#ESG performance & $-0.0582^{* * *}$ & $0.944^{* * *}$ \\
DebtEquity & 0.0134 & 1.014 \\
EBITTotrev & $-0.00236^{* * *}$ & $0.998^{* * *}$ \\
lnMarketCap & $0.0671^{* * *}$ & $1.069^{* * *}$ \\
lnRevenue & $0.371^{* *}$ & $1.449^{* *}$ \\
Observations & 0.310 & 1.364 \\
Number of ticker & 522 & 522 \\
\hline
\end{tabular}

*** $p<0.01, * * p<0.05, * p<0.1$

Source: the authors' calculations

Based on the results in Table 4, we can conclude that when ESG performance increases by one unit, the probability of having high corporate credit rating decreases by 5.6 percent. If a company is international, the likelihood of having a high corporate credit rating decreases by 82.6 percent, whereas internationalization does not affect the interrelationship between ESG activities and corporate credit rating.

To sum up, the implementation of ESG projects for companies of Latin America is negatively related to corporate financial performance, the reason is Latin American firms suffer from scarcity of financial resources, and for them investing in business expansion is more profitable and reliable than investing in ESG development ( $\underline{H 1 \text { is rejected }})$. When applying econometric models with the internationalization's moderating effect on the relationship between ESG activities and corporate financial performance, we determine that the ESG performance effect become insignificant for domestic firms ( $\mathrm{H1}$ is rejected $)$. Meanwhile, the internationalization weakens (H3 is rejected) the interrelationship between ESG activities and corporate financial performance. This is because, to comply with foreign investors and customers' requirements about sustainability, Latin American firms must, replace outdated technologies, improve work conditions for employees, and other social and managerial issues. However, all of these improvements demand significant financial investments. Investment in ESG projects increases the default likelihood ( $H 2$ is rejected), which confirms that such projects are expensive for these companies, and the effect of the internationalization is insignificant in the relation between ESG performance and default likelihood. GDP growth of the country, in which the firm is headquartered, positively affects corporate financial performance. Hence, we can assume that GDP growth may positively influence the 
relationship between ESG activities and corporate financial performance, because the higher economic development of the country is, the better conditions for the company to invest in operating activities and sustainability are ( $\underline{H 4 \text { is not rejected }})$.

\section{B. North America}

The United States and Canada are some of the largest economies worldwide, measured in terms of nominal GDP and ranked as first and tenth, respectively. As for ESG activities, Canada and the USA try to comply with new tendencies regarding ESG initiatives, for instance, they almost oblige companies to disclose their ESG achievements, and companies that do not disclose their ESG activities are considered indifferent to the environmental, social, and managerial issues. The US government is currently focused on developing climate policy, green infrastructure, and renewable energy.

Figure 2. The difference in ESG ratings between international and local firms from 2011 to 2019 $(1$ = international firms, $0=$ local firms $)$

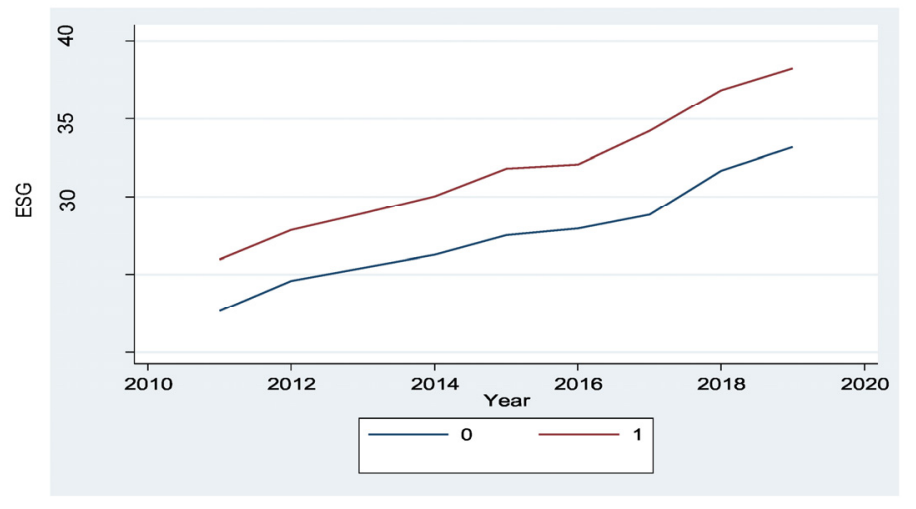

Figure 2 shows a gradual increase in the average value of ESG rating over the period from 2011 to 2019, and again international companies outperform domestic ones by demonstrating more successful ESG development. 
Table 5. The Relationship between Financial Performance and Investing in ESG Projects in North America

\begin{tabular}{|c|c|c|c|c|c|c|}
\hline VARIABLES & $\begin{array}{l}\text { North America } \\
\quad \text { (ROA1) }\end{array}$ & $\begin{array}{l}\text { North America } \\
\text { (ROA2) }\end{array}$ & $\begin{array}{l}\text { North America } \\
\text { (ROE1) }\end{array}$ & $\begin{array}{l}\text { North America } \\
\text { (ROE2) }\end{array}$ & $\begin{array}{l}\text { North America } \\
\text { (Market/Book1) }\end{array}$ & $\begin{array}{l}\text { North America } \\
\text { (Market/Book2) }\end{array}$ \\
\hline Mult & & $1.223^{*}$ & & 0.426 & & 17.24 \\
\hline ESG performance & -0.00140 & 0.0106 & $0.0727 * *$ & 0.0482 & $0.647 * * *$ & $0.443^{*}$ \\
\hline $\begin{array}{l}\text { Mult\#ESG } \\
\text { performance }\end{array}$ & & -0.0181 & & 0.0305 & & 0.254 \\
\hline lnRevenue & $1.106^{* * *}$ & $1.084 * * *$ & $2.886^{* * *}$ & $2.858 * * *$ & $6.437^{* *}$ & $5.941 * *$ \\
\hline CurrRatio & $0.910 * * *$ & $0.905^{* * *}$ & $0.657^{*}$ & $0.627^{*}$ & $2.738^{*}$ & 2.548 \\
\hline CAPEX intensity & $-0.0271 * * *$ & $-0.0270 * * *$ & $-0.220 * * *$ & $-0.215 * * *$ & -0.187 & -0.142 \\
\hline DebtEquity & $-0.00231 * * *$ & $-0.00228 * * *$ & $0.0327 * * *$ & $0.0328 * * *$ & $0.0164 * *$ & $0.0170 * *$ \\
\hline GDPgrowth & 0.179 & 0.181 & 0.625 & 0.635 & $8.153 * * *$ & $8.247 * * *$ \\
\hline Constant & $-20.48 * * *$ & $-20.76 * * *$ & $-54.50 * * *$ & $-54.06 * * *$ & -46.55 & -46.06 \\
\hline Observations & 2,934 & 2,934 & 2,934 & 2,934 & 2,934 & 2,934 \\
\hline Number of Ticker & 326 & 326 & 326 & 326 & 326 & 326 \\
\hline
\end{tabular}

$* * * p<0.01, * * p<0.05, * p<0.1$

Source: the authors' calculations

Based on the econometric results shown in Table 5, we can conclude that the increase in ESG performance leads to a rise in the corporate financial performance of North American firms (H1 is not rejected). According to the ROE1 model, when ESG performance increases by 1 unit, ROE increases by 0.0727 percentage points, whereas internationalization does not affect the relationship between corporate financial performance and ESG rating ( $\underline{H 3 \text { is rejected }})$. Based on the results of the Market/Book 1 model, if the ESG rating increases by 1 unit, the ratio of the firm's Total Market Value to the Total Asset Value of the firm increases by 0.647 percentage points. Statistically significant positive interrelationship exists between GDP growth of the country, in which the company is headquartered, and corporate financial performance based on Market/Book1 and Market/Book2 models. GDP growth may positively impact the dependence between ESG activities and corporate financial performance because the higher the economic development of the country is, the better conditions for the company to invest in operating activities and sustainability ( $\mathrm{H} 4$ is not rejected) . 
Table 6. Regression Analysis of the Changes in the Likelihood of Default

\begin{tabular}{lcc}
\hline \multicolumn{1}{c}{ VARIABLES } & North America & Odds ratio \\
\hline Mult & $-1.021^{* * *}$ & $0.360^{* * *}$ \\
ESG performance & $-0.0432^{* * *}$ & $0.958^{* * *}$ \\
Mult\#ESG performance & $0.0395^{* * *}$ & $1.040^{* * *}$ \\
DebtEquity & $-0.00499^{* * *}$ & $0.995^{* * *}$ \\
EBITREV & $0.0585^{* * *}$ & $1.060^{* * *}$ \\
lnMarketCap & $-0.277^{* * *}$ & $0.758^{* * *}$ \\
lnRevenue & $0.287^{* * *}$ & $1.332^{* * *}$ \\
Observations & 2,934 & 2,934 \\
Number of Ticker & 326 & 326 \\
\hline
\end{tabular}

*** $p<0.01, * * p<0.05, * p<0.1$

Source: the authors' calculations

According to the results of Table 6, ESG activities negatively affect corporate credit rating (H2 is rejected) . When the ESG rating increases by 1 unit, the probability of having high corporate credit rating decreases by 4.2 percent, whereas internationalization triggers a positive premium in these relationships.

Summing up, we can conclude that companies from North America are wealthy and affordable to implement ESG projects; also the USA and Canadian governments actively encourage firms to disclose ESG achievements. The ESG implementation requires a sufficient amount of investments because the increase in ESG rating causes the rise in the default probability, but when the company's sales expand outside the domestic market, ESG activities start negatively affecting the default likelihood; consequently, foreign investors and customers provide firms with sufficient funding and cash flows from sales, respectively, to continue effectively engaging in ESG initiates.

\section{Developing Asia}

Indian and Chinese firms have been chosen for the analysis of companies from Developing Asia. Chinese and Indian economies are considered some of the fastest-growing economies and ranked as 2nd and 6th largest economies globally, respectively. As for ESG initiatives, China has already demonstrated a willingness and ability to combat climate change. The country has deployed more solar and wind power systems than any other country in the world over the past five years. China accounts for 99 percent of global electric bus production and 50 percent of global electric vehicle sales. As for India, the country also develops sustainability-related strategies, for example, to reduce carbon emission and pollution from freight transport. Consequently, Developing Asia possesses favorable conditions to implement ESG projects. Goods produced by firms of these countries are valuable worldwide that encourages companies to persist in ESG activities increasingly. 
Figure 3. The difference in ESG ratings between international and local firms from 2011 to 2019 $(1=$ international firms, $0=$ local firms $)$

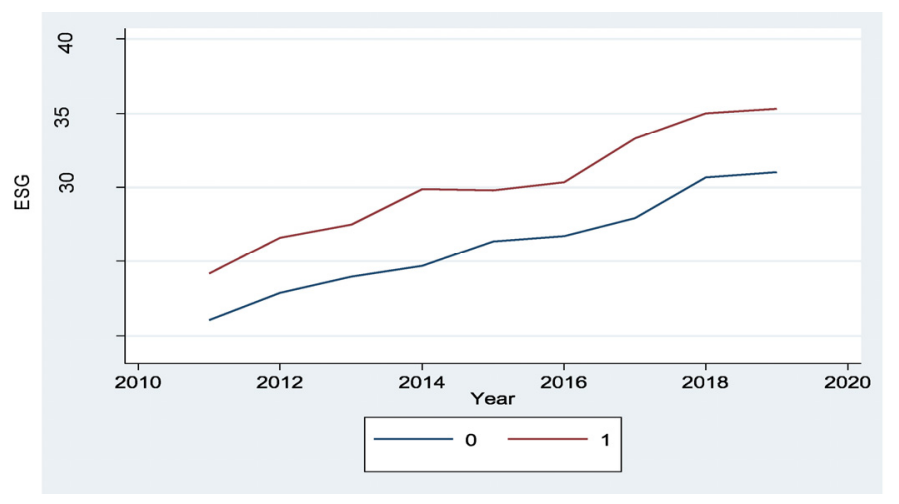

The graph demonstrates that on average, ESG rating slightly grows from 2011 to 2019, and multinational companies reflect greater ESG rating compared with domestic firms due to the need to comply with foreign laws, norms, and values (Figure 3).

Table 7. The Relationship between Financial Performance and Investing in ESG Projects in Developing Asia

\begin{tabular}{|c|c|c|c|c|c|c|}
\hline VARIABLES & $\begin{array}{c}\text { Developing } \\
\text { Asia (ROA1) }\end{array}$ & $\begin{array}{c}\text { Developing } \\
\text { Asia (ROA2) }\end{array}$ & $\begin{array}{c}\text { Developing } \\
\text { Asia (ROE1) }\end{array}$ & $\begin{array}{c}\text { Developing } \\
\text { Asia (ROE2) }\end{array}$ & $\begin{array}{l}\text { Developing Asia } \\
\text { (Market/Book1) }\end{array}$ & $\begin{array}{l}\text { Developing Asia } \\
\text { (Market/Book2) }\end{array}$ \\
\hline Mult & & 0.396 & & -0.268 & & 13.24 \\
\hline ESG performance & $-0.0415 * * *$ & $-0.0321 * *$ & $-0.0614^{*}$ & $-0.115 * * *$ & 0.235 & 0.0738 \\
\hline $\begin{array}{l}\text { Mult\#ESG } \\
\text { performance }\end{array}$ & & $0.0454 *$ & & $0.146^{* *}$ & & 0.459 \\
\hline lnRevenue & $0.728 * *$ & 0.229 & $1.096^{* *}$ & $1.116^{* *}$ & $-15.39 * * *$ & $-15.49 * * *$ \\
\hline CurrRatio & $0.373 * * *$ & $0.484 * * *$ & 0.0680 & 0.000746 & $9.991 * * *$ & $9.842 * * *$ \\
\hline CAPEX intensity & $0.0309 * *$ & $0.0223 *$ & $0.0578 *$ & $0.0551 *$ & 0.288 & 0.279 \\
\hline DebtEquity & $-0.0276 * * *$ & $-0.0285 * * *$ & $-0.0678 * * *$ & $-0.0691 * * *$ & $-0.167 * * *$ & $-0.169 * * *$ \\
\hline GDPgrowth & $0.430 * * *$ & $0.357 * * *$ & $1.053 * * *$ & $1.036^{* * *}$ & $10.73 * * *$ & $10.64 * * *$ \\
\hline Constant & $-11.48^{*}$ & -0.345 & -12.50 & -11.98 & $384.9^{* * *}$ & $387.1 * * *$ \\
\hline Observations & 1,467 & 1,467 & 1,467 & 1,467 & 1,467 & 1,467 \\
\hline Number of Ticker & 163 & 163 & 163 & 163 & 163 & 163 \\
\hline
\end{tabular}

*** $p<0.01, * * p<0.05, * p<0.1$

Source: the authors' calculations

The results of Table 7 reveal that ESG initiatives are negatively related to corporate financial performance measured through ROA. When the company's sales spread beyond the domestic market, the impact of ESG activities on corporate financial performance starts being positive, meaning that the internationalization generates additional cash flows allowing investing in ESG projects and earning profit. GDP growth has a statistically significant positive influence on corporate financial performance. For instance, based on the ROE2 model, when the GDP growth 
of the country, in which the firm is headquartered, rises by 1 percentage point, ROE increases by 1.036 percentage points, meaning that the economic development of the country plays one of the important roles in the company's successful performance.

Table 8. Regression Analysis of the Changes in the Likelihood of Default

\begin{tabular}{lcc}
\hline \multicolumn{1}{c}{ VARIABLES } & Asia Emerging & Odds ratio \\
\hline Mult & $-0.893^{* *}$ & $0.409^{* *}$ \\
ESG performance & 0.00210 & 1.002 \\
Mult\#ESG performance & $0.0471^{* * *}$ & $1.048^{* * *}$ \\
DebtEquity & $-0.0418^{* * *}$ & $0.959^{* * *}$ \\
EBITREV & $0.0957^{* * *}$ & $1.100^{* * *}$ \\
lnMarketCap & $-0.304^{* * *}$ & $0.738^{* * *}$ \\
lnRevenue & $0.355^{* * *}$ & $1.426^{* * *}$ \\
Observations & 1,467 & 1,467 \\
Number of ticker & 163 & 163 \\
\hline
\end{tabular}

*** $p<0.01, * * p<0.05, * p<0.1$

Source: the authors' calculations

Based on the results of Table 8 , we can conclude that internationalization positively influences the interrelationship between corporate credit rating and ESG activities (H2 is not rejected for international firms), confirming our conclusion after analyzing the random effects model, that internationalization generates additional cash flows allowing to invest in ESG projects and earn profit.

In summary, we can conclude that the implementation of ESG projects is negatively related to corporate financial performance ( $\mathrm{H1}$ is rejected $)$ until the company's sales extend beyond a domestic country (H3 is not rejected) because international investors may provide with additional funding, and international customers, which already strong demand for Chinese and Indian products, may reward these companies for participation in ESG activities by additionally increasing demand for their products. GDP growth of the country, in which the firm is headquartered, positively affects corporate financial performance, and hence we can assume that GDP growth may positively influence the relationship between ESG activities and corporate financial performance because the higher economic development of the country is, the better conditions for the company to invest in operating activities and sustainability ( $\mathrm{H} 4$ is not rejected) .

\section{Developed Asia}

South Korean and Japanese companies have been chosen for the analysis of firms from Developed Asia. Currently, Japanese companies actively engage in ESG activities by producing customer-oriented goods, enhancing their technologies to reduce emissions, and introducing more and more workplaces with good conditions and effective human capital management. Investments 
of Japanese firms in ESG activities have risen dramatically since 2016, albeit significantly lower compared to those of the USA and Europe. For South Korea, the country will introduce the rule obliging large companies, listed on the South Korean major stock market, to disclose their ESG activities since 2025.

Figure 4. The difference in ESG ratings between international and local firms from 2011 to 2019 $(1=$ international firms, $0=$ local firms $)$

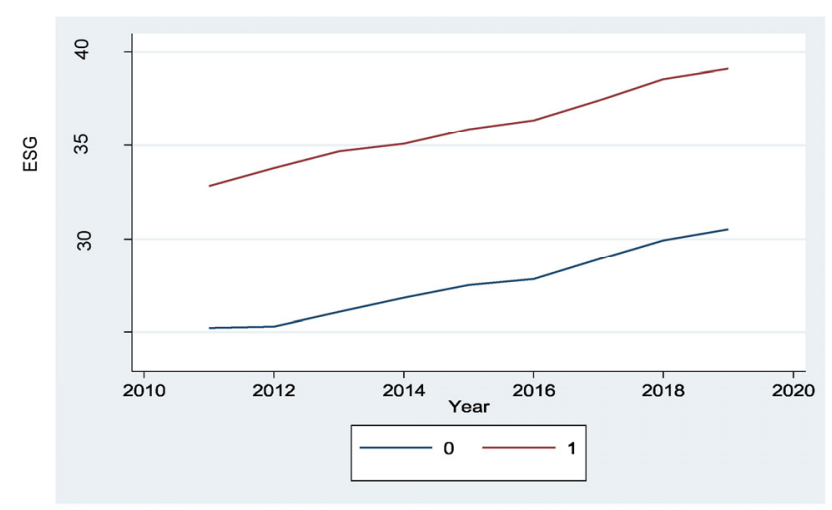

In contrast to other firms, the average value of the ESG rating of firms of Developed Asia does not increase gradually but remains unchanged. International companies demonstrate better ESG performance compared with local ones during the period from 2011 to 2019 (Figure 4).

Table 9. The Relationship between Financial Performance and Investing in ESG Projects in Developed Asia

\begin{tabular}{lcccccc}
\hline \multicolumn{1}{c}{ VARIABLES } & $\begin{array}{c}\text { Developed } \\
\text { Asia (ROA1) }\end{array}$ & $\begin{array}{c}\text { Developed } \\
\text { Asia (ROA2) }\end{array}$ & $\begin{array}{c}\text { Developed } \\
\text { Asia (ROE1) }\end{array}$ & $\begin{array}{c}\text { Developed } \\
\text { Asia (ROE2) }\end{array}$ & $\begin{array}{c}\text { Developed Asia } \\
\text { (Market/Book1) }\end{array}$ & $\begin{array}{c}\text { Developed Asia } \\
\text { (Market/Book2) }\end{array}$ \\
\hline Mult & & 0.217 & & $1.922^{*}$ & 10.63 \\
ESG performance & 0.00655 & 0.00628 & $0.0842^{* *}$ & 0.0190 & $0.749^{* * *}$ & $1.095^{* * *}$ \\
Mult\#ESG & & 0.0171 & & $0.0930^{* * *}$ & & $-0.510^{* * *}$ \\
performan ce & & & & & $-2.645^{*}$ \\
lnRevenue & 0.118 & 0.129 & 1.692 & $1.012^{* * *}$ & $-2.942^{*}$ & $5.136^{* * *}$ \\
CurrRatio & $0.679 * * *$ & $0.700^{* * *}$ & 0.429 & $0.752^{* * *}$ & $5.001^{* * *}$ & $0.425^{* * *}$ \\
CAPEXSales & $0.0518^{* * *}$ & $0.0514^{* * *}$ & 0.0631 & $0.111^{* * *}$ & $0.432^{* * *}$ & $-0.0270^{* * *}$ \\
DebtEquity & $-0.0177^{* * *}$ & $-0.0178^{* * *}$ & $-0.0905^{* * *}$ & $-0.0566^{* * *}$ & $-0.0275^{* * *}$ & $1.014^{*}$ \\
GDPgrowth & 0.00507 & 0.00772 & -0.229 & -0.0699 & $0.999^{*}$ & $91.17^{* * *}$ \\
Constant & 1.021 & 0.565 & -21.74 & $-9.885^{* *}$ & $104.5^{* * *}$ & 4,653 \\
Observations & 4,653 & 4,653 & 4,653 & 4,653 & 4,653 & 517 \\
Number of Ticker & 517 & 517 & 517 & 517 & & 517 \\
\hline
\end{tabular}

*** $p<0.01, * * p<0.05, * p<0.1$

Source: the authors' calculations 
According to the econometric results of Table 9, when ESG rating rises, the ratio of Total Market Value of firm to Total Asset Value of firm also increases, meaning that investors react positively if the company engages in sustainability ( $\mathrm{H1}$ is not rejected), although when the company expands its business beyond the domestic market, the relationship between the ratio of Total Market Value of firm to Total Asset Value of firm and ESG activities weakens by 0.51 percentage points ( $\mathrm{H3}$ is rejected). When the company is international, investors assume that more important projects exist than ESG initiatives. According to the ROE2 model, internationalization triggers the rise in corporate financial performance by 0.093 percentage points ( $\mathrm{H3}$ is not rejected). The increase in GDP growth of the country, in which the company is headquartered, leads to higher market valuation according to Market/Book1 and Market/Book2 models. Hence, GDP growth may positively influence the interrelationship between ESG activities and corporate financial performance because the higher economic development of the country is, the better conditions for the company to invest in operating activities and sustainability ( $\mathrm{H} 4$ is not rejected).

Table 10. Regression Analysis of the Changes in the Likelihood of Default

\begin{tabular}{lcc}
\hline \multicolumn{1}{c}{ VARIABLES } & Developed Asia & Odds ratio \\
\hline Mult & $-0.539^{* *}$ & $0.583^{* *}$ \\
ESG performance & $-0.0226^{* * *}$ & $0.978^{* * *}$ \\
Mult\#ESG performance & $0.0181^{* * *}$ & $1.018^{* * *}$ \\
DebtEquity & $-0.0624^{* * *}$ & $0.939^{* * *}$ \\
EBITREV & $0.183^{* * *}$ & $1.201^{* * *}$ \\
lnMarketCap & $-0.181^{* *}$ & $0.834^{* *}$ \\
lnRevenue & $0.142^{*}$ & $1.153^{*}$ \\
Observations & 4,653 & 4,653 \\
Number of Ticker & 517 & 517 \\
\hline
\end{tabular}

*** $p<0.01, * * p<0.05, * p<0.1$

Source: the authors' calculations

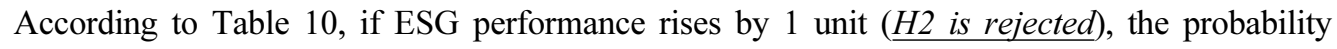
of having high corporate credit rating decreases by 2.2 percent. Internationalization strengthens the relationship between ESG activities and corporate credit rating.

Having analyzed both models, we can infer that internationalization strengthens the relationship between ESG activities and corporate financial performance and that between ESG activities and corporate credit rating. The reason is foreign customers and investors appreciate sustainabilityoriented companies and, in turn, provide them with additional cash flows, allowing these companies to invest more in ESG activities. The internationalization weakens the interrelationship between ESG initiatives and the ratio of Total Market Value of firm to Total Asset Value of firm, probably meaning that domestic investors assume that more important projects exist than ESG initiatives during the company's expansion outside the home country. 


\section{E. Western Europe}

Austrian, Belgian, the UK, and French companies have been chosen to analyze firms of Western Europe. As for ESG initiatives, almost 70 percent of the leading Western European companies encourage their managers based on at least one indicator of ESG.

Figure 5. The difference in ESG ratings between international and local firms from 2011 to 2019 $(1=$ international firms, $0=$ local firms)

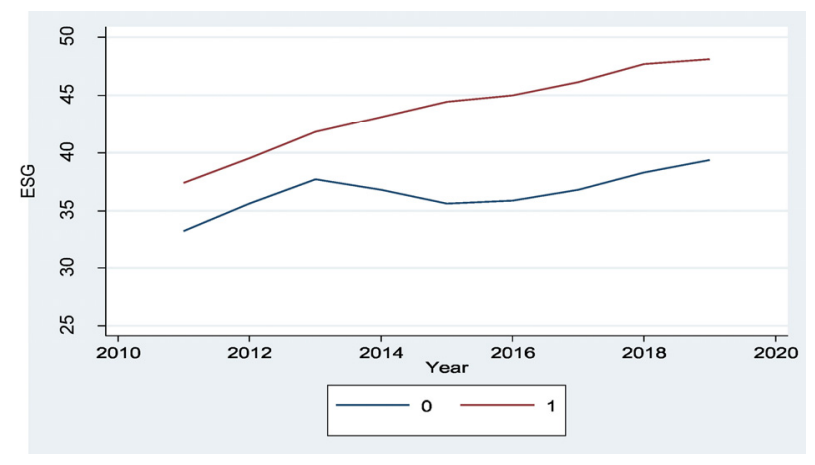

According to the given above graphs, firms of Western Europe demonstrate the same trends as firms of other regions (Figure 5).

Table 11. The Relationship between Financial Performance and Investing in ESG Projects in Western Europe

\begin{tabular}{|c|c|c|c|c|c|c|}
\hline VARIABLES & $\begin{array}{c}\text { Western Europe } \\
\text { (ROA1) }\end{array}$ & $\begin{array}{c}\text { Western Europe } \\
(\text { ROA2) }\end{array}$ & $\begin{array}{c}\text { Western Europe } \\
\quad(\mathrm{ROE} 1)\end{array}$ & $\begin{array}{c}\text { Western Europe } \\
\text { (ROE2) }\end{array}$ & $\begin{array}{l}\text { Western Europe } \\
\text { (Market/Book1) }\end{array}$ & $\begin{array}{l}\text { Western Europe } \\
\text { (Market/Book2) }\end{array}$ \\
\hline Mult & & -1.570 & & -6.330 & & 30.37 \\
\hline $\begin{array}{l}\text { ESG } \\
\text { performance }\end{array}$ & $-0.0329 * *$ & -0.0714 & $-0.155^{* * *}$ & $-0.325^{*}$ & $0.388 *$ & $0.755^{*}$ \\
\hline $\begin{array}{l}\text { Mult\#ESG } \\
\text { performance }\end{array}$ & & 0.0433 & & 0.189 & & -0.417 \\
\hline lnRevenue & 0.286 & 0.266 & $1.967^{*}$ & $1.894 *$ & $20.06 * *$ & 2.377 \\
\hline CurrRatio & $0.967 * * *$ & $0.971^{* * *}$ & -0.165 & -0.186 & -7.950 & -4.218 \\
\hline $\begin{array}{l}\text { CAPEX } \\
\text { Intensity }\end{array}$ & -0.00754 & -0.00744 & -0.0505 & -0.0502 & 0.189 & 0.0791 \\
\hline DebtEquity & $-0.00882 * * *$ & $-0.00889 * * *$ & $-0.0177 * * *$ & $-0.0180 * * *$ & -0.0335 & -0.0233 \\
\hline GDPgrowth & $0.632 * * *$ & $0.627 * * *$ & $1.799 * * *$ & $1.771 * * *$ & $5.786 * * *$ & $5.742 * * *$ \\
\hline Constant & -1.485 & 0.335 & -23.21 & -15.86 & -361.6 & 8.029 \\
\hline Observations & 1,053 & 1,053 & 1,053 & 1,053 & 1,053 & 1,053 \\
\hline $\begin{array}{l}\text { Number of } \\
\text { ticker }\end{array}$ & 117 & 117 & 117 & 117 & 117 & 117 \\
\hline
\end{tabular}


According to the econometric analysis results in Table 11, a statistically significant negative interrelationship exists between ESG activities and corporate financial performance based on ROE, ROA ( $\underline{H 1 \text { is rejected }}$ ), whereas Market/Book1 and Market/Book2 models demonstrate a positive market reaction to the increase in ESG activities ( $\mathrm{H1}$ is not rejected $)$. The company's internationalization has a statistically insignificant impact on the interrelationship between ESG initiatives and corporate financial performance ( $\mathrm{H3}$ is rejected $)$. GDP growth of the country, in which the company is headquartered, has a statistically significant influence at 1 percent level on corporate financial performance, and consequently, GDP growth may positively affect the interrelationship between ESG activities and corporate financial performance, because the higher economic development of the country is, the better conditions for the company to invest in operating and ESG activities ( $\mathrm{H} 4$ is not rejected).

Table 12. Regression Analysis of the Changes in the Likelihood of Default

\begin{tabular}{lcc}
\hline \multicolumn{1}{c}{ VARIABLES } & Western Europe & Odds ratio \\
\hline Mult & $1.960^{* *}$ & $7.098^{* *}$ \\
ESG performance & $0.0333^{*}$ & $1.034^{*}$ \\
Mult\#ESG performance & $-0.0583^{* * *}$ & $0.943^{* * *}$ \\
DebtEquity & $-0.0155^{* * *}$ & $0.985^{* * *}$ \\
EBITREV & $-0.0119^{* *}$ & $0.988^{* *}$ \\
lnMarketCap & $0.184^{*}$ & $1.202^{*}$ \\
lnRevenue & -0.149 & 0.862 \\
Observations & 1,053 & 1,053 \\
Number of Ticker & $\underline{117}$ & 117 \\
\hline$* * * p<0.01, * * p<0.05, * p<0.1$ & & \\
Source: the authors ${ }^{\prime}$ calculations & &
\end{tabular}

According to the odds ratio, if the company is multinational, the likelihood of having a high corporate credit rating increases more than seven times (Table 12). As for ESG activities, when ESG rating rises by 1 unit, the probability of having high corporate credit rating increases by 3.4 percent ( $\mathrm{H} 2$ is not rejected), whereas internationalization weakens the positive interrelationship between ESG activities and corporate credit rating. If the company is multinational, the probability of having high corporate credit rating decreases by 5.7 percent.

Hence, the market positively reacts to the increase in ESG activities, whereas accountingbased indicators of corporate financial performance demonstrate the opposite results. That is, the market prefers companies engaging in ESG initiatives and encouraging them, whereas such project is costly for these firms and negatively influence corporate financial performance measures such as ROA and ROE. ESG activities boost corporate credit rating, but internationalization weakens this boost. The reason is that the company generates additional cash flow due to their activities in ESG projects and declines their need in debt rising, but the internationalization 
demands a significant amount of financial resources, and hence the company increases the amount of borrowed funds, which increase the default likelihood.

\section{F. Eastern Europe}

Polish, Turkish, and Russian companies have been chosen for the analysis of firms from Eastern Europe. Companies from Eastern Europe have been trying to conform to the ESG reporting quality of their competitors of Western Europe, albeit to achieve the same level of ESG disclosure as the largest Western European companies demonstrate, companies from Eastern Europe have much work to do.

Figure 6. The difference in ESG ratings between international and local firms from 2011 to 2019 $(1$ = international firms, $0=$ local firms $)$

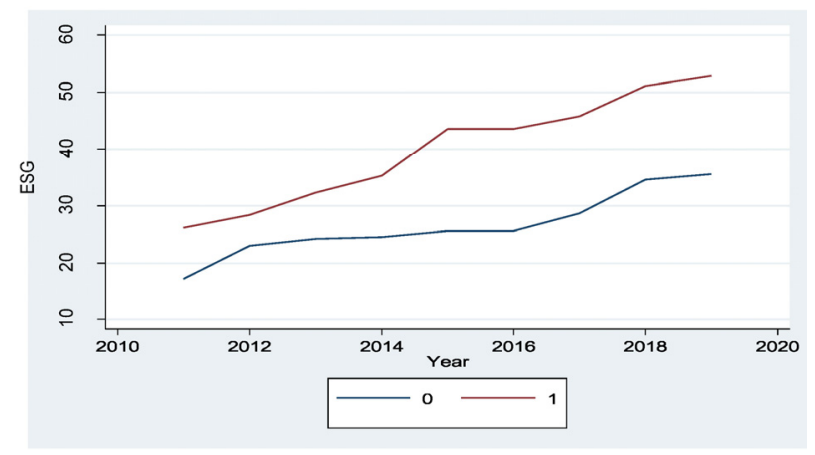

Figure 6 also demonstrates the upward trend in ESG activities within Eastern European companies, and the superior of multinational companies to domestic ones in ESG initiatives, these results agree with outcomes of already investigated regions. 
Table 13. The Relationship between Financial Performance and Investing in ESG Projects in Eastern Europe

\begin{tabular}{|c|c|c|c|c|c|c|}
\hline VARIABLES & $\begin{array}{c}\text { Eastern Europe } \\
\text { (ROA1) }\end{array}$ & $\begin{array}{c}\text { Eastern Europe } \\
\text { (ROA2) }\end{array}$ & $\begin{array}{c}\text { Eastern Europe } \\
\text { (ROE1) }\end{array}$ & $\begin{array}{c}\text { Eastern Europe } \\
\text { (ROE2) }\end{array}$ & $\begin{array}{l}\text { Eastern Europe } \\
\text { (Market/Book1) }\end{array}$ & $\begin{array}{l}\text { Eastern Europe } \\
\text { (Market/Book2) }\end{array}$ \\
\hline Mult & & -2.193 & & -13.71 & & -46.53 \\
\hline ESG performance & $0.0650 *$ & 0.0311 & $0.202 * *$ & -0.0796 & -0.242 & $-1.731 * * *$ \\
\hline $\begin{array}{l}\text { Mult\#ESG } \\
\text { performance }\end{array}$ & & 0.0443 & & 0.346 & & $1.682 * * *$ \\
\hline InRevenue & 0.536 & 0.620 & 1.287 & 1.587 & $-18.20 * *$ & $-17.70 * *$ \\
\hline CurrRatio & $1.855^{* * *}$ & $1.853 * * *$ & 0.877 & 0.895 & $-6.977 * *$ & $-7.046^{* *}$ \\
\hline CAPEX Intensity & $-0.203 * * *$ & $-0.207 * * *$ & $-0.596 * * *$ & $-0.627 * * *$ & -0.462 & -0.578 \\
\hline DebtEquity & $-0.0253 * * *$ & $-0.0240 * * *$ & -0.0210 & -0.0153 & $-0.0961^{*}$ & -0.0735 \\
\hline GDPgrowth & 0.114 & 0.119 & 0.449 & 0.471 & $2.290 * *$ & $2.206^{* *}$ \\
\hline Constant & -7.095 & -7.556 & -16.09 & -13.08 & $534.0^{* * *}$ & $561.7 * * *$ \\
\hline Observations & 270 & 270 & 270 & 270 & 270 & 270 \\
\hline Number of Ticker & 30 & 30 & 30 & 30 & 30 & 30 \\
\hline
\end{tabular}

*** $p<0.01, * * p<0.05, * p<0.1$

Source: the authors' calculations

Based on the econometric analysis in Table 13, the rise in ESG initiatives positively affects corporate financial performance based on ROA and $\mathrm{ROE}$ ( $\underline{H 1 \text { is not rejected }})$. In contrast, the internationalization of the company does not have a statistically significant impact on corporate financial performance based on accounting measures ( $H 3$ is rejected). According to the Market/ Book2 model, the increase in ESG performance by 1 unit decreases the ratio of Total Market Value of firm to Total Asset Value of firm by 1.731 percentage points ( $H 1$ is rejected), whereas the internationalization weakens this negative effect by 1.682 percentage points ( $\mathrm{H3}$ is not rejected $)$.

The rise in GDP growth of the country, in which the firm is headquartered, triggers the increase in a market-to-book ratio of more than 2 percentage points. Hence, GDP growth may positively impact the interrelationship between ESG activities and corporate financial performance because the higher the economic development of the country, the better the conditions for the company to invest in operating activities and sustainability ( $\mathrm{H} 4$ is not rejected).

According to the odds ratio, we receive surprising outcomes; that is, ESG activities do not possess any statistically significant influence on corporate credit rating ( $\underline{H 2 \text { is rejected }}$ ), even if the company is international. 
Table 14. Regression Analysis of the Changes in the Likelihood of Default

\begin{tabular}{lcc}
\hline \multirow{2}{*}{ VARIABLES } & $(1)$ & $(4)$ \\
\cline { 2 - 3 } Mult & Eastern Europe & Odds ratio \\
ESG performance & -0.408 & 0.665 \\
Mult\#ESG performance & 0.00475 & 1.005 \\
DebtEquity & -0.0180 & 0.982 \\
EBITREV & $-0.0124^{* * *}$ & $0.988^{* * *}$ \\
lnMarketCap & $0.0680^{* * *}$ & $1.070^{* * *}$ \\
lnRevenue & 0.409 & 1.505 \\
Observations & -0.197 & 0.822 \\
Number of Ticker & 270 & 270 \\
\hline$* * *$ & 30 & 30
\end{tabular}

*** $p<0.01, * * p<0.05, * p<0.1$

Source: the authors' calculations

Firms from Eastern Europe successfully invest in ESG projects, thereby attracting more investors and customers that provide firms with additional cash flows (Table 14). This conclusion is based on the results of the panel data model with random effects, whose results show that the increase in ESG activities enhances ROE and ROA. According to the ordered response logit model, ESG initiatives do not affect corporate credit rating that is we can assume that ESG project expenditures are compensated by cash flows generated by successfully implemented ESG initiatives. Internationalization has no effect on the interrelationship between ESG initiatives and corporate financial performance that probably means that both international and domestic firms equally successfully invest in ESG activities, however, the market reaction to the increase in ESG activities is negative, but it changes for international companies.

\section{G. The Middle East and Africa}

Companies from the Middle East and Africa try to keep up with their competitors from other regions in sustainability by investing in renewable energy or issuing green bonds and participating in other activities that will help reduce a negative impact on the environment. However, a small share of these companies disclose their ESG initiatives and their results. Some countries of this region are exposed to a high level of corruption, political uncertainty, and political instability, which can cause difficulties during the ESG initiatives implementation.

The graph depicts that, on average, the ESG rating of companies from the Middle East, and Africa gradually rises during the analyzed period from 2011 to 2019, and multinational companies demonstrate better performance in ESG activities compared with domestic ones, because of pressure from foreign customers, suppliers, and investors (Figure 7). 
Figure 7. The difference in ESG ratings between international and local firms from 2011 to 2019 ( 1 = international firms, $0=$ local firms)

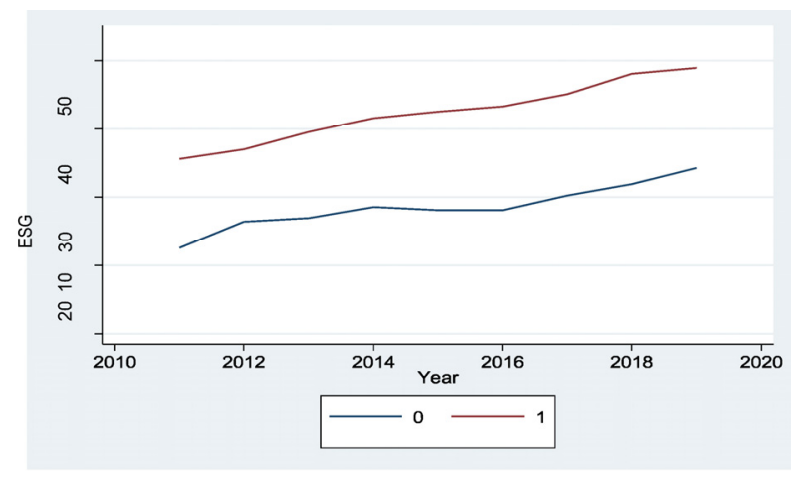

Table 15. The Relationship between Financial Performance and Investing in ESG Projects in the Middle East, and Africa

\begin{tabular}{|c|c|c|c|c|c|c|}
\hline VARIABLES & $\begin{array}{c}\text { The Middle } \\
\text { East and Africa } \\
\text { (ROA1) }\end{array}$ & $\begin{array}{c}\text { The Middle } \\
\text { East and Africa } \\
\text { (ROA2) }\end{array}$ & $\begin{array}{c}\text { The Middle } \\
\text { East and Africa } \\
(\mathrm{ROE} 1)\end{array}$ & $\begin{array}{c}\text { The Middle } \\
\text { East and Africa } \\
\text { (ROE2) }\end{array}$ & $\begin{array}{c}\text { The Middle } \\
\text { East and Africa } \\
\text { (Market/Book1) }\end{array}$ & $\begin{array}{c}\text { The Middle } \\
\text { East and Africa } \\
\text { (Market/Book2) }\end{array}$ \\
\hline Mult & & 3.152 & & 16.88 & & $131.0^{* * *}$ \\
\hline ESG performance & -0.0514 & 0.0745 & -0.127 & 0.395 & $-0.907 *$ & $2.080^{* *}$ \\
\hline $\begin{array}{l}\text { Mult\#ESG } \\
\text { performance }\end{array}$ & & -0.151 & & $-0.656^{* *}$ & & $-4.232 * * *$ \\
\hline lnRevenue & 0.188 & 0.331 & 1.894 & 2.305 & $23.96 * *$ & $22.09^{*}$ \\
\hline CurrRatio & $1.060^{*}$ & $1.170^{* *}$ & 1.690 & 2.207 & 2.466 & 2.892 \\
\hline CAPEXSales & 0.0227 & 0.0441 & -0.154 & -0.0838 & 0.608 & 0.683 \\
\hline DebtEquity & -0.00440 & -0.00352 & $0.141 * * *$ & $0.145^{* * *}$ & -0.000344 & 0.0172 \\
\hline GDPgrowth & $0.930^{* * *}$ & $0.982 * * *$ & $2.230 * * *$ & $2.381^{* * *}$ & $8.640 * * *$ & $9.260 * * *$ \\
\hline Constant & 3.087 & -3.276 & -30.46 & -54.11 & -371.2 & $-414.9 *$ \\
\hline Observations & 342 & 342 & 342 & 342 & 342 & 342 \\
\hline Number of Ticker & 38 & 38 & 38 & 38 & 38 & 38 \\
\hline
\end{tabular}

According to the econometric analysis results of Table 15, the increase in ESG activities does not have any influence on corporate financial performance measured through ROA and ROE ( 1 1 is rejected $)$, although, based on models ROE2 and Market/Book2, the internationalization declines the interrelationship between ESG activities and corporate financial performance $(\underline{H 3}$ is rejected). If the firm is international and ESG rating rises by 1 unit, ROE decreases by 0.656 percentage points, whereas the ratio of Total Market Value of firm to Total Asset Value of firm goes down by 4.232 percentage points. According to Market/Book2, the rise in ESG activities enhances the ratio of the firm's Total Market Value to the Total Asset Value of the firm ( $\mathrm{H1}$ is not rejected $)$, but the multinationalization weakens this positive effect. It can be 
a market positive reaction to news about the increase in ESG activities. According to the market's reaction, when companies are international, they have more important projects to invest in rather than ESG activities. GDP growth of the country, in which the firm is headquartered, positively affects corporate financial performance measured through ROA, ROE, and the ratio of Total Market Value of firm to Total Asset Value of firm. Consequently, GDP growth may positively affect the relationship between ESG activities and corporate financial performance because the higher economic development of the country, the better conditions for the company to invest in operating activities and sustainability ( $\mathrm{H} 4$ is not rejected $)$.

Table 16. Regression Analysis of the Changes in the Likelihood of Default

\begin{tabular}{lcc}
\hline \multicolumn{1}{c}{ VARIABLES } & The Middle East, and Africa & Odds ratio \\
\hline Mult & 0.774 & 2.169 \\
ESG performance & 0.0164 & 1.017 \\
Mult\#ESG performance & $-0.0395^{* *}$ & $0.961^{* *}$ \\
DebtEquity & $-0.00601^{* * *}$ & $0.994^{* * *}$ \\
EBITREV & $0.0717^{* * *}$ & $1.074^{* * *}$ \\
lnMarketCap & $-0.553^{* * *}$ & $0.575^{* * *}$ \\
lnRevenue & $0.365^{*}$ & $1.441^{*}$ \\
Observations & 342 & 342 \\
Number of ticker & 38 & 38 \\
\hline
\end{tabular}

$* * * p<0.01, * * p<0.05, * p<0.1$

Source: the authors' calculations

Table 16 shows that ESG activities do not have a statistically significant influence on corporate credit rating, although if the company is international, the increase in ESG initiatives by 1 unit triggers the decrease in the likelihood of having a high corporate credit rating by 3.9 percent (H2 is rejected).

To sum up, a statistically significant negative interrelationship exists between ESG activities and corporate financial performance, solely when the company is international. When the company's sales spread beyond the domestic market, additional costs must be incurred for the successful expansion of the company's business outside the country, and simultaneous costs for sustainability projects might be not affordable yet.

\section{Discussion}

We discuss obtained results and compare them of each region according to the stated hypotheses. 
H1: Investing in ESG projects boosts corporate financial performance.

According to accounting-based performances, the first hypothesis is not rejected for firms headquartered in North America, Eastern Europe, and Developed Asia. Based on market-based performance, firms headquartered in Western Europe, North America, and Developed Asia have a positive relationship between ESG activities and corporate financial performance. As for firms from the Middle East, and Africa, ESG initiatives do not affect accounting-based performances, whereas the market reacts positively to the rise in ESG activities of domestic firms, but negatively to the increase in this type of initiative of international firms. Finally, investing in ESG projects causes a decline in corporate financial performance for firms that are headquartered in Latin America and Developing Asia.

H3: Internationalization of the company strengthens the relationship between corporate financial performance and investing in ESG projects.

Internationalization leads to the positive relation between ESG activities and corporate financial performance for firms headquartered in Developing Asia and Developed Asia according to accounting-based indicators, whereas the market positively reacts to news about increasing in ESG activities of international companies that are headquartered in Eastern Europe. Internationalization does not influence the aforementioned relationship for firms headquartered in North America, Western Europe and negatively affects the dependence between ESG activities and corporate financial performance for companies from the Middle East, Africa, and Latin America.

H2: Investing in ESG projects decreases the likelihood of the company default.

ESG initiatives decline corporate credit rating for companies that are headquartered in Latin America, North America, Developed Asia, whereas internationalization weakens this negative effect for companies from North America and Developed Asia. International companies from Developing Asia enhance their corporate credit rating by engaging in ESG projects. As for Western European companies, ESG initiatives boost corporate credit rating, but internationalization weakens this positive effect. Multinationalization also triggers the inverse relationship between ESG initiatives and corporate credit rating for firms that are headquartered in the Middle East, and Africa. Finally, ESG practices have an insignificant impact on corporate credit rating for firms from Eastern Europe.

We can infer that international companies headquartered in regions, whose countries belong to leading economies globally, have the positive influence of ESG initiatives on corporate financial performance and corporate credit rating. These regions are North America, Developing 
Asia, and Developed Asia. Furthermore, firms of Eastern Europe demonstrate the effective implementation of ESG activities, which might be caused by adjacent to Western Europe. Eastern Europe learns from the experience of Western Europe and imposes projects aimed at achieving sustainability to keep up with peers from Western Europe, albeit Western Europe reveals worse results than Eastern Europe. However, they may implement more advanced ESG projects that are more expensive in comparison with ESG projects of Eastern Europe. Finally, the Middle East, Africa, and Latin America do not benefit due to ESG project implementation that may be caused by the high level of corruption, political uncertainty, and political instability of some countries included in these regions.

H4: A country's characteristics affect the relationship between corporate financial performance and investing in ESG projects.

This hypothesis is not rejected for each region because the better macroeconomic indicators of the country are, in which the firm is headquartered, the better conditions are for each firm not only for expansion or maintenance of the company's operational activity but for engagement in additional activities such as sustainability.

H5: The company's headquartered region affects the relationship between financial performance and investing in ESG projects.

This hypothesis is not rejected. We received various results for each region because each region has its economic development, political stability, institutional conditions, and cultural values, and hence the dependence between ESG initiatives and corporate financial performance and the dependence between ESG initiatives and corporate credit rating is different for each region.

Thus, the North American firms illustrate the positive interrelationship between accountingbased the company's performance and ESG activities, whereas Western firms cannot boast the same results. Canadian and American governments require companies to disclosure their ESG achievements, otherwise, firms will be considered as indifferent to the environmental, social, and managerial issues. Moreover, under the influence of new ESG tendencies, customers appreciate goods produced by firms actively involved in ESG activities. Goods and services produced by North American companies are valuable all over the world, and engagement in ESG activities increases demand for these goods. The aforementioned reasons such as the governments' requirements, high demand for the North American goods, and active participation in ESG activities by The North American firms may lead to better results in comparison with Western European firms. Emerging Asian firms also demonstrate a positive relationship between accounting-based the company's performance and ESG activities in comparison with Western European firms, but 
this conclusion is true only for international Emerging Asia firms because Chinese and Indian products are highly demanded all over the world, and their persistence in ESG activities strengths demand by foreign customers for goods produced by Chinese and Indian firms.

\section{Conclusion}

Existing empirical studies have been dedicated to examining the interrelationship between ESG activities and corporate financial performance of companies either belonging to developed markets or both developed and emerging markets. Grouping firms of Latin American countries and those of Developing Asia countries into one is inefficient because of the distinct economic development, political stability, institutional conditions, and cultural values of these regions. Hence, our contribution to the existing literature is analyzing the relationship between ESG initiatives and corporate financial performance by region. We applied two models, which helped investigate the impact of ESG practices on the company's profitability, and analyzed whether ESG initiatives may cause the company's default because of the costliness of this kind of initiative. We also examine whether the internationalization of the company strengthens the relationship between corporate financial performance and investment in ESG projects.

Our findings are different for each of the seven analyzed regions, indicating that the company's headquarter region affects the relationship between financial performance and investing in ESG projects. We conclude that only Latin American companies experience significant challenges during the implementation of ESG projects. Hence, we can suggest that the more successful regions in ESG development must help Latin American firms to introduce such initiative without making losses by providing additional funding and professional staff with knowledge and abilities to help implement ESG practices effectively.

We suggest investors who desire to invest in firms that are actively participating in ESG activities consider international companies headquartered in developing and Developed Asia or North America because they reveal the positive influence of ESG initiatives on their corporate financial performance and credit rating.

This empirical research has limitations that could be included in future studies. For instance, we investigate firms without dividing them into groups according to the industry they operate. We analyze only whether the company is international or not, but considering a spread of the company's sales by region would be more effective. For example, suppose the international company's sales are concentrated in Latin America. In that case, the company does not have many incentives to engage in ESG practices actively. In contrast, if the multinational company's sales are concentrated in North America, the company has many incentives to implement ESG projects, which then will attract more investors and customers. 


\section{References}

Aguilera-Caracuel, J., Guerrero-Villegas, J., Vidal-Salazar, M. D., \& Delgado-Márquez, B. L. (2015). International cultural diversification and corporate social performance in multinational enterprises: The role of slack financial resources. Management International Review, 55(3), 323-353.

Arayssi, M., Dah, M., \& Jizi, M. (2016). Women on boards, sustainability reporting and firm performance. Sustainability Accounting, Management and Policy Journal, 7(3), 376-401.

Badayi, S. A., Matemilola, B. T., \& Wei Theng, L. (2020). Does corporate social responsibility influence firm probability of default? International Journal of Finance \& Economics, 136(3), 26-44.

Bhaskaran, R. K., Ting, I. W. K., Sukumaran, S. K., \& Sumod, S. D. (2020). Environmental, social and governance initiatives and wealth creation for firms: An empirical examination. Managerial and Decision Economics, 41(5), 710-729.

Cheng, B., Ioannou, I., \& Serafeim, G. (2014). Corporate social responsibility and access to finance. Strategic Management Journal, 35(1), 1-23.

Churet, C., \& Eccles, R. G. (2014). Integrated reporting, quality of management, and financial performance. Journal of Applied Corporate Finance, 26(1), 56-64.

Crespi, F., \& Migliavacca, M. (2020). The Determinants of ESG rating in the financial industry: the same old story or a different tale? Sustainability, 12(16), 6398.

De Lucia, C., Pazienza, P., \& Bartlett, M. (2020). Does Good ESG lead to better financial performances by firms? Machine learning and logistic regression models of public enterprises in Europe. Sustainability, 12(13), 5317.

Devalle, A., Fiandrino, S., \& Cantino, V. (2017). The linkage between ESG performance and credit ratings: a firm-level perspective analysis. International Journal of Business and Management, 12(9), 53-65.

Dorfleitner, G., Kreuzer, C., \& Sparrer, C. (2020). ESG controversies and controversial ESG: about silent saints and small sinners. Journal of Asset Management, 21(5), 393-412.

Duque-Grisales, E., \& Aguilera-Caracuel, J. (2019). Environmental, social and governance (ESG) scores and financial performance of Multilatinas: Moderating effects of geographic international diversification and financial slack. Journal of Business Ethics, 168(2), 315-334.

Espahbodi, L., Espahbodi, R., Juma, N., \& Westbrook, A. (2019). Sustainability priorities, corporate strategy, and investor behavior. Review of Financial Economics, 37(1), 149-167.

Fatemi, A., Glaum, M., \& Kaiser, S. (2018). ESG performance and firm value: The moderating role of disclosure. Global Finance Journal, 38, 45-64.

Friede, G., Busch, T., \& Bassen, A. (2015). ESG and financial performance: aggregated evidence from more than 2000 empirical studies. Journal of Sustainable Finance \& Investment, 5(4), 210-233.

Garcia, A. S., \& Orsato, R. J. (2020). Testing the institutional difference hypothesis: A study about environmental, social, governance, and financial performance. Business Strategy and the Environment, 29(8), 3261-3272.

Garcia, A. S., Mendes-Da-Silva, W., \& Orsato, R. J. (2017). Sensitive industries produce better ESG performance: Evidence from emerging markets. Journal of Cleaner Production, 150, 135-147.

Gjergji, R., Vena, L., Sciascia, S., \& Cortesi, A. (2021). The effects of environmental, social and governance 
disclosure on the cost of capital in small and medium enterprises: The role of family business status. Business Strategy and the Environment, 30(1), 683-693.

Jo, H., \& Na, H. (2012). Does ESG reduce firm risk? Evidence from controversial industry sectors. Journal of Business Ethics, 110(4), 441-456.

Liu, Y., Saleem, S., Shabbir, R., Shabbir, M. S., Irshad, A., \& Khan, S. (2021). The relationship between corporate social responsibility and financial performance: A moderate role of fintech technology. Environmental Science and Pollution Research, 28(16), 20174-20187.

Lo, K. Y., \& Kwan, C. L. (2017). The effect of environmental, social, governance and sustainability initiatives on stock value-Examining market response to initiatives undertaken by listed companies. Corporate Social Responsibility and Environmental Management, 24(6), 606-619.

Lopez-Valeiras, E., Gomez-Conde, J., \& Fernandez-Rodriguez, T. (2016). Firm size and financial performance: intermediate effects of indebtedness. Agribusiness, 32(4), 454-465.

Lu, W. M., Wang, W. K., \& Lee, H. L. (2013). The relationship between corporate social responsibility and corporate performance: Evidence from the US semiconductor industry. International Journal of Production Research, 51(19), 5683-5695.

Miralles-Quirós, M. M., Miralles-Quirós, J. L., \& Redondo Hernández, J. (2019). ESG performance and shareholder value creation in the banking industry: International differences. Sustainability, 11(5), 1404.

Nekhili, M., Boukadhaba, A., \& Nagati, H. (2021). The ESG-financial performance relationship: Does the type of employee board representation matter? Corporate Governance: An International Review, 29(2), 134-161.

Nekhili, M., Nagati, H., Chtioui, T., \& Rebolledo, C. (2017). Corporate social responsibility disclosure and market value: Family versus nonfamily firms. Journal of Business Research, 77, 41-52.

Nollet, J., Filis, G., \& Mitrokostas, E. (2016). Corporate social responsibility and financial performance: A non-linear and disaggregated approach. Economic Modelling, 52, 400-407.

Park, S. B. (2018). Multinationals and sustainable development: Does internationalization develop corporate sustainability of emerging market multinationals? Business Strategy and the Environment, 27(8), 1514-1524.

Prado, G. F., Piekarski, C. M., da Luz, L. M., de Souza, J. T., Salvador, R., \& de Francisco, A. C. (2020). Sustainable development and economic performance: Gaps and trends for future research. Sustainable Development, 28(1), 368-384.

Raimo, N., Caragnano, A., Zito, M., Vitolla, F., \& Mariani, M. (2021). Extending the benefits of ESG disclosure: The effect on the cost of debt financing. Corporate Social Responsibility and Environmental Management, 28(4), 1412-1421. https://doi.org/10.1002/csr.2134

Shaukat, A., Qiu, Y., \& Trojanowski, G. (2016). Board attributes, corporate social responsibility strategy, and corporate environmental and social performance. Journal of Business Ethics, 135(3), 569-585.

Sun, W., \& Cui, K. (2014). Linking corporate social responsibility to firm default risk. European Management Journal, 32(2), 275-287.

Tunio, R. A., Jamali, R. H., Mirani, A. A., Das, G., Laghari, M. A., \& Xiao, J. (2021). The relationship between corporate social responsibility disclosures and financial performance: a mediating role of 
employee productivity. Environmental Science and Pollution Research, 28(9), 10661-10677.

Uzliawati, L., Yuliana, A., Januarsi, Y., \& Santoso, M. I. (2018). Optimisation of capital structure and firm value. European Research Studies Journal, 2, 705-713.

Verheyden, T., Eccles, R. G., \& Feiner, A. (2016). ESG for all? The impact of ESG screening on return, risk, and diversification. Journal of Applied Corporate Finance, 28(2), 47-55.

Wong, W. C., Batten, J. A., Mohamed-Arshad, S. B., Nordin, S., \& Adzis, A. A. (2021). Does ESG certification add firm value? Finance Research Letters, 39, 101593.

Yu, E. P. Y., Guo, C. Q., \& Luu, B. V. (2018). Environmental, social and governance transparency and firm value. Business Strategy and the Environment, 27(7), 987-1004.

Zubeltzu-Jaka, E., Andicoechea-Arondo, L., \& Alvarez Etxeberria, I. (2018). Corporate social responsibility and corporate governance and corporate financial performance: Bridging concepts for a more ethical business model. Business Strategy \& Development, 1(3), 214-222. 
Appendix 1. Sample for Analysis

\begin{tabular}{|c|c|c|c|c|c|c|}
\hline \multicolumn{7}{|c|}{ Region } \\
\hline Latin America & Eastern Europe & $\begin{array}{c}\text { Middle East, } \\
\text { and Africa }\end{array}$ & $\begin{array}{c}\text { Asia } \\
\text { (Emerging) }\end{array}$ & $\begin{array}{c}\text { Asia } \\
\text { (Developed) }\end{array}$ & Western Europe & North America \\
\hline Chile & Poland & Saudi Arabia & China & Japan & France & USA \\
\hline Mexico & Turkey & Qatar & India & South Korea & UK & Canada \\
\hline Brazil & Russia & Kuwait & & & Austria & \\
\hline Argentina & & Kenya & & & Belgium & \\
\hline \multirow[t]{7}{*}{ Colombia } & & Israel & & & & \\
\hline & & South Africa & & & & \\
\hline & & Oman & & & & \\
\hline & & Nigeria & & & & \\
\hline & & Saudi Arabia & & & & \\
\hline & & United Arab & & & & \\
\hline & & Emirates & & & & \\
\hline
\end{tabular}

Appendix 2. Correlation Matrix for Variables of the Panel Data Model (Local Firms)

\begin{tabular}{lccccccccc}
\hline \multicolumn{1}{c}{ Variables } & $(1)$ & $(2)$ & $(3)$ & $(4)$ & $(5)$ & $(6)$ & (7) & (8) & (9) \\
\hline (1) ROA & 1.000 & & & & & & & & \\
(2) ROE & 0.740 & 1.000 & & & & & & & \\
(3) EVTotAssets & 0.604 & 0.443 & 1.000 & & & & & & \\
(4) ESG & 0.016 & 0.045 & 0.034 & 1.000 & & & & & \\
(5) LnRevenue & 0.019 & 0.101 & -0.017 & 0.400 & 1.000 & & & & \\
(6) CurrRatio & 0.269 & 0.017 & 0.189 & -0.103 & -0.257 & 1.000 & & & \\
(7) CAPEXSales & -0.056 & -0.039 & -0.007 & 0.119 & -0.014 & -0.080 & 1.000 & & \\
(8) DebtEquity & -0.191 & 0.114 & -0.002 & 0.063 & 0.106 & -0.248 & 0.058 & 1.000 \\
(9) GDPgrowth & 0.117 & 0.100 & 0.184 & -0.111 & 0.060 & -0.087 & 0.098 & 0.033 & 1.000 \\
\hline
\end{tabular}

Appendix 3. Correlation Matrix for Variables of the Panel Data Model (International Firms)

\begin{tabular}{|c|c|c|c|c|c|c|c|c|c|}
\hline Variables & (1) & (2) & (3) & (4) & (5) & (6) & (7) & (8) & (9) \\
\hline (1) ROA & 1.000 & & & & & & & & \\
\hline (2) $\mathrm{ROE}$ & 0.696 & 1.000 & & & & & & & \\
\hline (3) EVTotAssets & 0.619 & 0.427 & 1.000 & & & & & & \\
\hline (4) ESG & -0.001 & 0.026 & 0.030 & 1.000 & & & & & \\
\hline (5) LnRevenue & -0.046 & 0.041 & -0.091 & 0.327 & 1.000 & & & & \\
\hline (6) CurrRatio & 0.196 & 0.038 & 0.091 & -0.137 & -0.140 & 1.000 & & & \\
\hline (7) CAPEXSales & -0.090 & -0.003 & 0.006 & 0.174 & 0.039 & -0.203 & 1.000 & & \\
\hline (8) DebtEquity & -0.184 & 0.163 & -0.024 & 0.035 & 0.093 & -0.144 & 0.482 & 1.000 & \\
\hline (9) GDPgrowth & 0.070 & 0.044 & 0.166 & -0.127 & 0.076 & -0.093 & 0.075 & 0.009 & 1.000 \\
\hline
\end{tabular}


92 Journal of Economic Integration Vol. 37, No. 1

Appendix 4. Correlation Matrix for Variables of the Ordered Response Logit Model (Local Firms)

\begin{tabular}{lcccccc}
\hline \multicolumn{1}{c}{ Variables } & $(1)$ & $(2)$ & $(3)$ & $(4)$ & $(5)$ & $(6)$ \\
\hline (1) Creditrating & 1.000 & & & & & \\
(2) ESG & -0.080 & 1.000 & & & & \\
(3) DebtEquity & -0.363 & 0.035 & 1.000 & & & \\
(4) EBITREV & 0.117 & 0.196 & 0.007 & 1.000 & & \\
(5) lnMarketCap & 0.020 & 0.392 & 0.031 & 0.424 & 1.000 & 1.000 \\
(6) LnRevenue & -0.115 & 0.327 & 0.093 & -0.056 & 0.656 & \\
\hline
\end{tabular}

Appendix 5. Correlation Matrix for Variables of the Ordered Response Logit Model (International Firms)

\begin{tabular}{lcccccc}
\hline \multicolumn{1}{c}{ Variables } & $(1)$ & $(2)$ & $(3)$ & $(4)$ & $(5)$ & \\
\hline (1) Creditrating & 1.000 & & & & \\
(2) ESG & -0.020 & 1.000 & & & & \\
(3) DebtEquity & -0.402 & 0.063 & 1.000 & & & \\
(4) EBITREV & 0.189 & 0.110 & 0.001 & 1.000 & & \\
(5) lnMarketCap & 0.078 & 0.418 & 0.002 & 0.426 & 1.000 \\
(6) LnRevenue & -0.111 & 0.400 & 0.106 & -0.005 & 0.741 & 1.000 \\
\hline
\end{tabular}

